\title{
MR. JUSTICE BLACK AND FEDERAL TAXATION
}

\author{
RANDOLPH E. PAUL†
}

ON August 12, 1937, President Roosevelt nominated Hugo Black, senior Senator from Alabama, to be Associate Justice of the Supreme Court to replace Justice Van Devanter, who had retired on June 2, 1937. It was President Roosevelt's first appointment to the Court. The nomination was confirmed by the Senate on August 17, 1937. The nominee took his seat on October 4, 1937. Today, eighteen troubled years later, he sits on the right hand of a younger Chief Justice. He is the only member of the 1937 Bench who is living today. ${ }^{2}$

\section{Civil War in a High Place}

Justice Black came to the Supreme Court at a critical moment in the country's history. It was also a period of crisis for the Supreme Court. ${ }^{3}$ On May 27, 1935, the Court had handed down the Schechter decision, invalidating the

iLate member of the District of Columbia, New Jersey and New York Bars.

1. 302 U.S. iii n.3 (1937).

2. Justice Reed, who sits on the left hand of the Chief Justice, was Solicitor General during the 1937 term.

3. Cf. Jackson, The Struggle for Judicial Suprearacy 124 (1941).

4. A.L.A. Schechter Poultry Corp. v. United States, 295 U.S. 495 (1935). See also Panama Refining Co. v. Ryan, 293 U.S. 388 (1935). For a discussion of the Schechter case, see Curtis, Lions Under the Throne 113 (1947).

On February 6, 1956, not long after the completion of this article, Mr. Paul was mortally stricken while he was testifying before the Joint Congressional Committee on the Economic Report. The Journal joins, in mourning the loss, a multitude of Mr. Paul's friends and admirers. One of these, Professor Fred Rodell, writes:

"Young men who come out of law school with their ideals still on high often seem to face a nasty dilemma. Should they fit their ideals to their future work and so lower their integrity-or should they fit their work to their ideals and so lower their incomes? I suggest that, instead of making either unpleasant choice, they give some thought to the rare carcer of Randolph Paul.

"Randolph Paul was the ablest tax lawyer in the United States. No one knew so well as he all the ins and outs and arounds and beneaths of the Internal Revenue Code. This knowledge he sold to men and companies, who stood in line to buy it. But outside of court and office, he steadfastly refused-almost alone among top tax lawyers-to serve as professional spokesman for his clients. Disturbed by the very gaps and inequities in the Code that favored those who could afford his counsel, he fought without cease-as writer, teacher and government advisor-for tax fairness and tax reform. It could truly be said of him that he publicly tried to put himself privately out of business.

"Crusader that he was, there was none of the righteous air of the crusader about Randolph. A warm and gentle and mellow man with a soft voice and smile, he won to him a myriad of friends. His death is our deep loss, just as his life was a rich example to us of decency in the practice of law." 
code-making provisions of Roosevelt's NIRA. Chief Justice Hughes, speaking for a unanimous Court, had held that Congress could not, under the guise of regulating interstate commerce, give to the President "virtually unfettered" discretion to make whatever codes he thought necessary for the rehabilitation of industry. Even Justice Cardozo, concurring, objected to delegation of legislative power which he thought was "running riot."

Donald Richberg, Chairman of the NIRA Board, and Solicitor General Reed, who had argued the Schechter case, were downcast. Others, including Senators Borah of Idaho and King of Utah, were elated. A frustrated President did not conceal his disappointment. A few days after the Schcchter decision he shocked an eager press conference with a statement that the Court had deprived the federal government of all control over economic and social conditions by interpreting the Commerce Clause of the Constitution in the light of the "horse-and-buggy" days of 1787 when it was written." To him the Schechter "sick-chicken" case was the Supreme Court's most important-and deplorable-ruling since the Dred Scott decision which precipitated the Civil War.?

The AAA, another favorite piece of New Deal legislation, was soon to suffer a similar fate. The constitutionality of this Act had been argued before the Supreme Court in December 1935. An able advocate had stood before the Court to plead in dramatic fashion the case of the America he loved, praying that the "land of the regimented" might not in his time be accepted as a worthy" substitute for "the land of the free." 8 On January 6, 1936, a bare majority of the Court, still under the spell of Mr. Pepper's mystical eloquence, decided that the AAA was unconstitutional. ${ }^{9}$

The majority opinion may have been a "tortured construction of the Constitution," as an outraged Justice Stone declared in a bitter dissent joined in

5. A.L.A. Schechter Poultry Corp. v. United States, supra note 4, at $\mathbf{5 5 3 .}$

6. Cf. Curtis' statement: "Time's chariot had forged ahead of the old judicial bus." CurTIs, op. cit. supra note 4 , at 83 .

I select the Schechter case for specific comment because it precipitated this protest from the President. There had been several storm signals. The Hot Oil case was one. Panama Refining Co. v. Ryan, 293 U.S. 388 (1935). Four Justices had dissented from the Court's decision in the Gold Clause cases, handed down on February 18, 1935. Norman v. Baltimore \& O.R.R., 294 U.S. 240 (1935) ; Nortz v. United States, 294 U.S. 317 (1935) ; Perry v. United States, 294 U.S. 330 (1935). On May 6, 1935, the Supreme Court held the Railroad Retirement Act unconstitutional. Railroad Retirement Bd. v. Alton R.R., 295 U.S. 330 (1935). On May 27, 1935, it struck down the Frazier-Lemke Farm Debtors' Relici Act. Louisville Joint Stock Land Bank v. Radford, 295 U.S. 555 (1935). On the sam: day the Court decided that the President was without inherent power to remove a Fcderal Trade Commissioner. Humphrey's Ex'r v. United States, 295 U.S. 602 (1935).

7. 2 Pusex, Charles Evans Hughes 742 (1951).

8. JACKson, op. cit. supra note 3 , at 131.

9. United States v. Butler, 297 U.S. 1 (1936). See also Anniston Mig. Co. v. Davis, 301 U.S. 337 (1937) ; Rickert Rice Mills Inc. v. Fontenot, 297 U.S. 110 (1936) ; cf. Mulford v. Smith, 307 U.S. 38 (1939). For a discussion of the Butler case, see CunTIs, $n t$. cit. supra note 4 , at 121. 
by Justices Brandeis and Cardozo, ${ }^{10}$ but nonetheless it took away $\$ 500$ million of revenue from a budget otherwise in balance except for relief expenditures, and precipitated a crisis for the revenue. A baffled Congress, whose power to tax and spend no longer included the power "to relieve a nation-wide economic maladjustment by conditional gifts of money," 11 had no recourse but to turn to new sources of revenue. A little later the Court struck down the Bituminous Coal Act. ${ }^{12}$ To put things crudely, the Court had reached a new high in "nuisance value"13 in obstructing the Administration's efforts to cope with the economic and social conditions of the Depression. ${ }^{14}$

The President used harsh terms in the 1936 election campaign. $\mathrm{He}$ called the reactionaries of the day, who sought through concentration of economic power to control the lives of less fortunate persons and even to direct governmental action, "economic royalists"-comparing them to the Royalists and 'Tories of the eighteenth century who had tried in vain to prevent the nation's attainment of political freedom. He added that intelligent conservatives had long known that worthy institutions could be conserved only by adjusting them to changing times. On February 5, 1937, soon after his landslide election victory, the President made his famous attempt to put new blood, new vigor, new experience and new outlook into a Supreme Court that was hesitating between two worlds. ${ }^{15}$ The Supreme Court packing bill never passed, but a marshalled public opinion achieved at least part of the presidential objective. Certainly, it

10. United States v. Butler, 297 U.S. 1, 87 (1936). It has been asserted that the bitter tone of this dissent almost lost the vote of Justice Brandeis. 2 Pusey, Crandes Evans Hughes 745 (1951).

11. United States v. Butler, supra note 10 , at $\$ 8$ (dissenting opinion per Stone, J.).

12. Carter v. Carter Coal Co., 298 U.S. 238 (1936) ; cf. Sunshine Coal Co. v. Adams, 310 U.S. 381 (1940). For discussion of the Carter case, see CunTIs, op. cit. supra note 4, at 134; 2 Pusex, Charles Evans Hughes 746 (1951).

13. Curtis, op. cit. supra note 4 , at 45 .

14. See Home Blds. \& Loan Ass'n v. Blaisdell, 290 U.S. 398 (1934); Nebbia v. New York, 291 U.S. 502 (1934) ; Railroad Retirement Bd. v. Alton R.R., 295 U.S. 330 (1935) ; Louisville Stock Land Bank v. Radford, 295 U.S. 555 (1935) ; Humphrey's Ex'r v. United States, 295 U.S. 602 (1935) ; Colgate v. Harvey, 296 U.S. 404 (1935); Ashwander v. Tennessee Valley Authority, 297 U.S. 288 (1936) ; Jones v. SEC, 298 U.S. 1 (1936) ; Ashton v. Cameron County Dist., 298 U.S. 513 (1936); Morehead v. New York $e x$ rel. Tipaldo, 298 U.S. 587 (1936). See also Norman v. Baltimore \& O.R.R., 294 U.S. 240 (1935); Nort2 v. United States, 294 U.S. 317 (1935) ; Perry v. United States, 294 U.S. 330 (1935).

15. Sce the President's Message of February 5, 1937, to the Seventy-fifth Congress, H.R. Doc. No. 142, 75th Cong., Ist Sess.; Attorney General Cummings' letter to the President of February 2,1937; and the President's address broadcast from the White House on March 9, 1937, all reproduced in JAckson, op. cit. supra note 3, at 328-51. See also RosENMIAN, WORKLNG WITH ROOSEVELT 146 (1952).

Roosevelt was not the first President to show impatience with old age on the Supreme Court. In the first year of his administration Taft wrote to Senator Lodge: "It is an outrage that the four men ["those old fools," Taft called them] on the bench who are over seventy should continue there and thus throw the work and responsibility on the other five." 1 Pringle, The Life and Times of William Howard Taft 530 (1939). 
became clear by White Monday, March 29, $1937,{ }^{16}$ or at the latest by April 12, $1937,{ }^{17}$ that discretion was going to be the better part of judicial valor. At least the climate of the Court's opinion suddenly changed. ${ }^{18}$ Although the battle for a new Court was lost, the war to sustain the New Deal's legislation was definitely won. ${ }^{19}$ Later in 1937 a vacancy gave the President the opportunity to appoint Senator Black to the Court. In a short span of later years the President was able to put on the Court a number of Justices of his own choosing. ${ }^{20}$

\section{A New BRAND of Economics}

As Justice Black came to the Supreme Court, restless spirits were busy disturbing the academic peace of the economists. Arguments to the Supreme

16. West Coast Hotel Co. v. Parrish, 300 U.S. 379 (1937), sustaining the constitutionality of the Minimum Wage Act of Washington and overruling Adkins v. Children's Hospital, 261 U.S. 525 (1923), was decided on March 29th. It has been claimed that President Roosevelt's "court-packing" assault on the Court had no bearing whatever on this "about-face" of the Court. 2 Pusey, Crarles Evans Hughes 703, 757, 766, 771 (1951). But Pusey admits that it did "clinch the victory of the liberal-minded men within the Court." 2 id. at 703. It has been cynically observed that "a switch in time saves nine." Freund, Review and Federalism, in Carn, Suprene Court and Supreme Law 93 (1954). See also Rosenman, op. cit. supra note 15 , at 161.

17. On this date the Court announced its decisions in NLRB v. Jones \& Laughlin Steel Corp., 301 U.S. 1 (1937) ; NLRB v. Fruehauf Co., 301 U.S. 49 (1937) ; NLRB v. Friedman-Harry Clothing Co., 301 U.S. 58 (1937); and Associated Press v. NLRB, 301 U.S. 103 (1937), upholding the National Labor Relations Act.

18. Morgan v. United States, 298 U.S. 468 (1936), 304 U.S. 1 (1938), 307 U.S. 183 (1939) ; Landis v. North American Co., 299 U.S. 248 (1936) ; Duke Power Co. v. Grenwood County, 299 U.S. 259 (1936) ; United States v. Curtiss-Wright Corp., 299 U.S. 304 (1936); Kentucky Whip \& Collar Co. v. Illinois Cent. R.R., 299 U.S. 334 (1937); United States v. Hudson, 299 U.S. 498 (1937). See Holyoke Water Power Co. v. American Writing Paper Co., 300 U.S. 324 (1937); West Coast Hotel Co. v. Parrish, 300 U.S. 379 (1937) ; Sonzinsky v. United States, 300 U.S. 506 (1937) ; Wright v. Vinton Branch, 300 U.S. 440 (1937) ; Virginian Ry. v. System Federation 40, Ry. Employees Dep't, AFL, 300 U.S. 515 (1937) ; NLRB v. Jones \& Laughlin Steel Corp., supra note 17; NLRB v. Fruuhauf Co., supra note 17; NLRB v. Friedman-Harry Clothing Co., supro note 17; Associated Press v. NLRB, supra note 17; Herndon v. Lowry, 301 U.S. 242 (1937) ; Cincinnati Soap Co. v. United States, 301 U.S. 308 (1937) ; Senn v. Tile Layers Protective Union, 301 U.S. 468 (1937) ; Carmichael v. Southern Coal Co., 301 U.S. 495 (1937); Steward Mach. Co. v. Davis, 301 U.S. 548 (1937) ; Helvering v. Davis, 301 U.S. 619 (1937) ; Alabama Power Co. v. Ickes, 302 U.S. 464 (1938) ; Electric Bond \& Share Co. v. SEC, 303 U.S. 419 (1938) ; United States v. Bekins, 304 U.S. 27 (1938) ; Erie R.R. v. Tompkins, 304 U.S. 64 (1938) ; Currin v. Wallace, 306 U.S. 1 (1939); Tennessee Elec. Power Co. v. Tennessee Valley Authority, 306 U.S. 118 (1939) ; Mulford v. Smith, 307 U.S. 38 (1939) ; United States v. Rock Royal Co-op, 307 U.S. 533 (1939) ; Coleman v. Miller, 307 U.S. 433 (1939) ; H. P. Hood \& Sons, Inc. v. United States, 307 U.S. 588 (1939).

Roosevelt once referred to the "definite turning point" in 1937 in a Court which had been thwarting the common will of a majority of the American people. 2 PUSEY, CHanLEs Evans Hugres 766 (1951). See also Curtis, op. cit. supra note 4, at 159; Rosenman, $o p$. cit. supra note 15 , at 161 .

19. RoSENMAN, op. cit. supra note 15 , at 161.

20. After Hugo Black, President Roosevelt appointed Justices Reed, Franlfurter, 
Court in favor of experimental legislation designed to relieve an extraordinary emergency were beginning to depart from established doctrines of laissez faire and to put unprecedented emphasis upon the promotion of the general welfare. Moreover, an English economist named Keynes, who had acquired great wealth and was later to acquire a title, joined intellectual forces with an American banker named Eccles, who was also being unfaithful to his wealthy class, to preach startling doctrines of a compensatory economy. To these prophets of a new economic deal, and to many who followed in their rapidly moving footsteps, debts were the other side of investment and not in themselves sinful. Nor was saving an unadulterated virtue. In their opinion the forces of supply and demand would not, as the classical economists thought, necessarily keep the economy at the full employment level. The interest rate was not a perfect mechanism which assured that demand for investment goods would always be forthcoming in an amount sufficient to utilize all resources not being used for meeting consumer demand. Investment sometimes needed the encouragement of governmental action; government was an indispensable partner of business rather than its patron. Perhaps worst of all in the eyes of some, this new fiscal philosophy called for a tax system which would counteract tendencies toward disproportionate saving, and promote tendencies to enlarge consumption to leep it in step with rises in productive capacity.

This was a persuasive and an ominous rationalization of a progressive tax system which would impose a heavier burden upon high bracket incomes, which are largely saved, than upon low bracket incomes, which are largely spent. It is hardly surprising that the higher income groups did not feel like taking these new heresies lying down. The opposition of many became almost religious in its intensity; a national deficit became in protesting minds a criminal act; and even the ravages of depression were thought by some to be preferable to profligate government spending. But there was ultimate victory in modified form for many of the Keynesian doctrines, and an ultimate demonstration of the truth of Keynes' observation that "the power of vested interests is vastly exaggerated compared with the gradual encroachment of ideas. ... [I]t is ideas, not vested interests, which are dangerous for good or evil,"21 and rule the world. For Keynes commanded the future from his study more than $\mathrm{Na}$ poleon had from his throne. Many of his ideas triumphed in the ideological battles that began in the mid-thirties, and have by now been translated into practices that would have been unthinkable in the golden twenties.

\section{Taxes in a Great Depression}

Even Roosevelt's worst enemies would hardly have disagreed with his assertion that the mid-thirties were "changing times." By the middle of 1937, change,

Douglas, Murphy, Byrnes, Jackson and Rutledge. In 1941 he raised Associate Justice Stone to Chief Justice.

21. Kixnes, The General Theory of Employment, Interest and Money 383-84 (1936). 
with its long arm, its disturbing touch, its decree of things not yet manifest, was making what was left of wealth sorrowful and afraid. Newness had suddenly acquired a new prevalence and scope and acceleration, so that the years of the lives of men then in high places began to measure not some small growth or rearrangement or moderation of what they had learned in childhood, but a great upheaval. Depression and gloom gripped a formerly ecstatic economy. New and suspicious brands of taxation were finding favor on Capitol Hill. In 1936 Congress had stunned the business and financial world by passing an undistributed profits tax suggested by a heretical President. The bill enacted was not the Administration proposal, and even the Senate version of the bill was not to the liking of Senators Black and LaFollette of the Finance Committee, who suggested substantial amendment. Their substitute bill would have collected $\$ 600$ million annually from the "privileged" higher income group which was avoiding the higher individual income taxes. ${ }^{22}$ Joined by Senator Norris, Senators Black and LaFollette fought for the Administration bill on the floor of the Senate. They fought in vain, and the bill that did pass came to a sad and quick end in $1939^{23}$ in response to a vigorous campaign of objection throughout the short period of its existence.

The undistributed profits tax was not the only villain of the troubled times that brought Hugo Black to the Supreme Court. In 1935 President Roosevelt had suggested a tax upon inheritances which "bless neither those who bequeath nor those who receive," 24 and the Congress of which Black was a member had responded with increased estate tax rates. ${ }^{25}$

The most dramatic events were taking place in June and July of 1937, just before Black's appointment to the Supreme Court. A revived Treasury, no longer reconciled to tax avoidance de lut.e, was presenting to a joint congressional committee a lurid and unbelievable story of tax avoidance. ${ }^{26}$ Witnesses

22. 80 CoNG. REc. $\$ 809$ (1936).

23. Revenue Act of $1936, \S 14,49$ Stat. 1655, repealed by Int. Rev. Code of 1939, $\S 15$, 53 Stat. 9.

24. H.R. ReP. No. 1681, 74th Cong., 1st Sess. 2 (1935).

25. See Paul, Federal Estate and Gift Taxation 14 (1942).

26. A lurid tale was unfolded before the Joint Committee. In order to siphon assets and income out of the United States, prominent American citizens had deserted the protection and advantages of the established corporate laws of the states in their country to put their assets in corporations established under the corporate laws of Nassau, an insignificant foreign island in the Atlantic Ocean, known principally as a winter pleasure resort, and in corporations established under the laws of other neighboring foreign jurisdictions such as Panama, Newfoundland and Prince Edward Island. Some American taxpayers were claiming wholly fictitious interest deductions for so-called loans from a company incorporated in the Bahama Islands which masqueraded as an insurance company. Domestic "incorporated pocketbooks," formed to insulate interest and dividends from the individual income tax, had multiplied like mushrooms. The owners of farms, racing stables, and even yachts, had incorporated their pleasures to make them businesses. One wealthy woman supplied her husband with pocket money by having the corporation that owned her country estate employ her husband as a manager. Multiple trusts were being used to obtain additional 
at public hearings before the Joint Committee on Tax Evasion and Avoidance described schemes and mentioned names. The "red herring" investigation, as it was called, filled newspapers with scandalous detail. A hot summer was cooler than many tempers. Though it provided "juicy copy," to use a term coined by Time Magazine, the press was not happy with the investigation. The New York Times conceded that the government should not tolerate evasion or fraud, but wondered if the Administration itself had set an example of scrupulous fairness. The New York Herald Tribune accused the "master drawer of herrings" of trying to give the impression that the failure of the rich to pay their income taxes, rather than some failures of the Administration, was responsible for the deficit. In impersonal language David Lawrence made personal reference to substantial charitable contributions by the First Lady of the land which were certainly in a different moral, and even legal, category from most of the avoidance schemes disclosed in the hearings. Senator Vandenberg used the investigation as a springboard for another reference to his favorite subject. "I wish," he said, "there was as much enthusiasm about stopping loopholes in expenditures. If we took all income of tax-dodgers, we would still be sunk in a tragic deficit."

In the Revenue Act of $1937^{27}$ Congress responded with some stern measures to curb tax avoidance of the bold sort revealed in the hearings. The Act became law on August 26, 1937, just after Justice Black's confirmation. As he later discovered, it fell far short of making the tax structure avoidance-proof, but it closed for good and all a number of the loopholes the President had called to the attention of Congress. It did not attempt to deal with community property, family partnerships, pension trusts and percentage depletion-subjects which had been mentioned by the President. But tax avoidance was never again to lue the simple matter it had been previously; it was destined to develop into a finer and subtler art, requiring more skillful devices, greater imagination, and a closer attention to detail.

\section{Tax Laly at a Crossroads}

A consciousness of the inadequacy of many accepted notions of law had come to lawyers perhaps even before dissatisfaction with their established creeds began to plague some of the more open-minded of the economists. "In the brief space of about seventy years," said Justice Stone in 1937, "our law has been called upon to accommodate itself to changes of conditions, social and economic, more marked and extensive in their creation of new interests requiring legal protection and control than occurred in the three centuries which followed the

persunal exemptions and to split income into large numbers of separate units each of which would start with a low tax bracket. Leading cartoonists, violinists and motion picture actors were resorting to the device of incorporating their personal talents. Hearings Before thi Joint Committee on Tax Evasion and Avoidance, 75th Cong., 1st Sess. (1937). See l'aul, The Bachground of the Revenue Act of 1937, 5 U. CHr. L. REv. 41 (1937).

27. 50 STAT. 813 . 
discovery of America."28 This description of the developments creating new necessities for law in the period prior to 1937 would be a vast understatement of the tumbling stream of events that followed Justice Black's appointment to the Supreme Court. Franklin D. Roosevelt made his famous, prophetic quarantine speech in 1937. In September 1939, German troops marched into Poland, and - in the vivid metaphor of a Chinese statesman-the sky was suddenly "black with the wings of chickens coming home to roost." The inevitable quickly followed. Early on a Sunday morning in December 1941, a Japanese air squadron descended from the blue of the Hawaiian skies to cripple the American Navy. Just as suddenly the law had to face the problems of World War II. In a short time it was being forced to carry a heavy load associated with price and wage control, rationing, credit control, foreign funds control, renegotiation, and a burden of additional tax controversy incident to war rates of taxation. The complications of a scarce labor market and military procurement added to the responsibilities put upon law in this riotous period.

World War II also changed the pace and scale of fiscal development. Experience taught an incredulous people that an internal debt of $\$ 275$ billion does not wreck a prosperous nation. In one year the federal budget rose to more than twice the amount of the national income of the depression year 1933, and to even more than the national income of the halcyon year 1929. Unemployment all but disappeared. The anemic purchasing power of the thirties suddenly became an eager giant ready to devour much more than the country's busy industrial plant could produce. Goods, not buyers, were lacking; a sellers' market replaced a buyers' market of more than a decade. A country grown weary of deflation had more inflation than it wanted. The new objective was to find means of production to win the war and at the same time supply goods for the constantly increasing civilian spending power created by war activities. War had brought too much prosperity. ${ }^{29}$

World War II and the years that followed also brought new meanings and values and magnitudes to taxation. It was out of all question to pay completely for the war as we went. That would have wrecked the production effort, so essential to winning the war. The home front problem was inflation, with danger potentials almost as great and evil as war itself. Taxation was used not only to help finance the war effort but, in partnership with direct controls and assisted by an unexpected pattern of savings, to control inflation. There was some inflation, but military victory in the war abroad finally came to a country unravaged by inflation at home. Something else came too-a realization by many people that a nation can thrive under a staggering burden of taxation, and that taxation is one of the most valuable instruments of economic control the world has ever known. No longer would taxes be merely the exactions of a greedy government that spends and spends and spends, or even a

28. Stone, The Common Law in the United States, in The Future of the Conmon LAW 129 (1937).

29. See Paul, Taxation in the United States 279 (1954). 
government that fails to spend enough. No longer would taxes be for revenue only; thenceforth, the power to tax, in association with other governmental powers, would be exercised in the light of a new sense of federal responsibility for the welfare of the economy. ${ }^{30}$ It would be a power to fulfill a better destiny for the American people.

\section{Justice Black's Qualifications for the Supreme Court}

Of such were the times in which Hugo Black assumed the responsibilities of a Justice of the Supreme Court. From the perspective of today it is startling to consider how myopic was the discussion, in the late thirties, of his qualifications for the role he has performed so well. Few talked at the time about the Senator's capacity to deal with the legal aspects of the problems many new tax and fiscal urgencies would bring to the Supreme Court. Indeed, the problems themselves were only dimly visible on a distant horizon. There was, however, a widespread belief that Black was not sufficiently learned in the intricacies of the law to serve competently on the highest Court of the land. In May of 1938 Marquis Childs reported that Black was causing his colleagues on the Court "acute discomfort and embarrassment" because he was "unable to carry his share of the heavy burden of work that falls on the Court." 31 In the light of the Justice's performance this was puzzling comment even at the time it was made. The fact was that few men have come to the Court better equipped.

The Justice had had a meager formal training in the law, it is true. ${ }^{32}$ But so had John Marshall, ${ }^{33}$ and so have other Supreme Court Justices. ${ }^{34}$ From an obscure beginning Black had risen to eminence in the practice of law; much of this practice had been in the appellate courts. ${ }^{35}$ He had had eighteen months' experience as a police court judge. He had seen considerable service as a prosecuting attorney. A Democrat, he had been selected by Republican Attorney General Stone to represent the Department of Justice in some important Prohibition cases. He had been elected to the Senate in 1926 and by 1937 had served in that body for almost two terms. ${ }^{36}$ During this service he learned

30. Cf. Employment Act of 1946, 60 STAT. 23, 15 U.S.C. $\$ \$ 1021-24$ (1952).

31. Childs, The Supreme Court To-day, 176 Harper's Magazine 581, 582 (1938). Eight years later Childs wrote that Black "worked harder than perhaps any justice in the history of the court" to "vindicate himself and to justify in the law his liberal opinions." McCune, The Nine Young Mien 33 (1947).

32. See preceding article, Frank, Mr. Justice Black: A Biographical Appreciation, 65 YALE L.J. 454, 455 (1956).

33. The closest John Marshall came to a formal education was a year's tutoring by a visiting minister and several months' schooling in Latin at Westmoreland Academy when he was fourteen. Marshall did spend six weeks attending lectures on the law given at William and Mary College. See Rodell, NiNe Men: A Political History of tHe SUPREME COURT FRON 1790 To 1955 , at 80 (1955).

34. For instance, Justices Miller and the first Harlan.

35. See J. P. Frank, Mr. Justice Black, The Man and His Opinions 35 (1949).

36. Among other things, while in the Senate he had conducted an investigation of mail subsidies and the public utility holding company investigation. This was a fight with a twelve billion dollar industry which had almost the entire press massed solidly behind it. 
from Senator LaFollette "much of the technical aspects of tax law."37 He was a vigorous fifty-one years old when he was nominated.

Black had supplemented his slight schooling by reading on a broad scale. The first book he read after his election to the Senate was Adam Smith's $W$ ealth of Nations. John Draper's History of the Intellectual Development of Europc led him on to much historical reading, including the writings of Franklin, Hamilton and John Adams, and all of Jefferson's voluminous writings; the records of the Federal Constitutional Convention and of the state ratifying conventions; numerous biographies of Revolutionary and nineteenth century American political leaders; Warren's and Myers' Supreme Court histories; most of the writings of Charles Beard; and numerous other historical worlss. His reading in Greek, Roman and European history, though less comprehensive, was extensive, and included translations of Herodotus, Thucydides, Plutarch, Suetonius, Seneca and Cicero.

Black's reading in other fields was far more than a sampling, and gave him "a comfortable acquaintance with the social sciences and the humanities." $38 \mathrm{He}$ read Shakespeare frequently, and Milton, and the romantic English poets of the nineteenth century. He read nineteenth century American writers such as Hawthorne, Thoreau and Twain. In government and economics he read, among others, Montesquieu, Rousseau, Locke, Bryce, Mill, Marx and Spencer. He particularly cherished Veblen. In philosophy he read Aristotle, Spinoza, and some of St. Thomas Aquinas and St. Augustine. His thorough reading of William James and John Dewey awaited a summer after his appointment to the Court which he devoted to modern legal philosophy and the American philosophers in whom that legal philosophy originates.

Those who criticized Black for lack of learning in the intricacies of the law made out a weak case for their point. True, he had never been a professor, ${ }^{30}$ and his judicial experience had been a limited one on a police court. ${ }^{40}$ Unlike Brandeis and Cardozo he had never published any scholarly books. But he had been phenomenally successful in practice, and had had considerable experience in public life. He had applied himself diligently to the lessons of experience. His qualifications for the Court compared favorably with those of many eminent previous appointees, including John Marshall, Louis D. Brandeis and Charles Evans Hughes. ${ }^{41}$ He had had more experience in practice than Holmes

37. J. P. Frank, Mr. Justice Black, The Man and His Opinions 62 (1949).

38. Id. at 47.

39. Three of Roosevelt's eight appointees had been law school professors or deans: Douglas, Frankfurter and Rutledge.

40. This prior judicial experience exceeded, however, that of six of the other seven Roosevelt appointees. Twelve of the twenty Justices appointed between 1897 and 1937 had had prior judicial experience.

41. See Frankfurter, The Supreme Court of the United States, in Law and Poutucs 21, 31 (1939).

Beveridge quotes Schmidt, a writer-contemporary of Chief Justice Miarshall: "Mr. Marshall can hardly be regarded as a learned lawyer. His acquaintance with the Roman jurisprudence as well as with the laws of foreign countries was not very extensive. He was 
or Cardozo. He had had more experience in public service than Pierce Butler or the later appointed Felix Frankfurter. Altogether, the impression is unavoidable that the criticism based upon an alleged deficiency in legal learning camouflaged objections to other qualities brought to light by Black's public record and particularly by his work in his second Senate term.

There is, moreover, an odd irrelevance in the stress, in much of the discussion about any Supreme Court appointment, on the appointee's learning in the law. The postulates of discussion need more analysis than is usually given to the subject, and less reticence than often characterizes the discussion. For one thing, learning in the law is a vague, immeasurable abstraction that defies definition. Possibly the central theme of the concept is a knowledge of past law in the sense of many precedents and the principles that have accumulated throughout the centuries. But this kind of knowledge, whatever it may be, can be gained from many sources. A complete formal education in the arts and the law is hardly a guarantee that it has been acquired.

But even more important, it must be remembered that most of the major questions presented to the Supreme Court cannot be answered out of the books that record the thousands of answers to questions previously presented. ${ }^{42}$ The questions that must be decided by the Court are often difficult and delicate questions of fact ${ }^{43}$ that strict logic and a judicious selection among rival precedents can answer in favor of either side of a controversy. ${ }^{44}$ A resourceful judge can give almost any conclusion a logical form. ${ }^{45}$ But as a basis for de-

what is called a common lawyer in the best \& noblest acceptation of that term." 2 BEveridge, The Life of John Marshall 178 (1916).

42. See Frankfurter, The Zeitgeist and The Indiciary, in LAw AND Politics 4-5 (1939).

43. Justice Brandeis' dissenting opinion in Burnet v. Coronado Oil \& Gas Co., 285 U.S. 393, 410-11 (1932), contains a paragraph that is well worth quoting:

"In the cases which now come before us there is seldom any dispute as to the interpretation of any provision. The controversy is usually over the application to existing conditions of some well-recognized constitutional limitation. This is strikingly true of cases under the due process clause when the question is whether a statute is unreasunable, arbitrary or capricious ; of cases under the equal protection clause when the question is whether there is any reasonable basis for the classification made by a statute; and of cases under the commerce clause when the question is whether an admitted burden laid by a statute upon interstate commerce is so substantial as to be deemed direct. These issues resemble, fundamentally, that of reasonable care in negligence cases, the determination of which is ordinarily left to the verdict of the jury. In every such case the decision, in the first instance, is dependent upon the determination of what in legal parlance is called a fact, as distinguished from the declaration of a rule of law. When the underlying fact has been found, the legal result follows inevitably. The circumstance that the decision of that fact is made by a court, instead of by a jury, should not be allowed to obscure its real character."

44. See Brant, Storar Over the Constitution 241 (1936) ; Llewellyn, The Branble Bush 156 (1930) ; Douglas, Stare Decisis, 49 Colum. L. Rev. 735, 736 (1949) ; Hamilton, Judicial Process, in 8 Encxc. of the Soctal Sciences 450, 451 (1932); Stone, supra note 28 , at 140 .

45. Holmes, Collected Legal Papers 181 (1952). 
cision, logic must yield first place to experience, and in the Supreme Court "the felt necessities of the time, the prevalent moral and political theories, intuitions of public policy, avowed or unconscious," have "a good deal more to do than the syllogism in determining the rules by which men should be governed." ${ }^{46}$ There is in the equation of most important decisions of the Supreme Court a clash of policy, an element of imponderable conflict between competing social and economic philosophies or forces in our society. And as Justices Holmes and Stone have intimated, the prejudices that a judge shares with his fellow men and the individual predilections of each Justice toward the problem before the Court may affect his decision." "Traditional beliefs, acquired convictions, an outlook on life, and a conception of social ends" are some of the deep forces that tug at judges. ${ }^{48}$

It is, in sum, a myth that the Supreme Court is either an impersonal or a nonpolitical body. It makes many political decisions, ${ }^{49}$ especially in constitutional matters," not in the "sense of partisanship but in the sense of policymaking."' This political role of the Court has been too obscure to laymen, and even to many lawyers. Constitutional interpretation, and to a large extent statutory interpretation, compel the translation of policy into judgment. In this process of interpretation the Justices of the Court gather meaning not only from reading the Constitution and the statutes, but also from reading life. ${ }^{52}$

These are some of the considerations which influence Presidents in their selection of Supreme Court Justices. Of course Presidents look to an appointee's legal learning and equipment, his experience at the bar, his reputation

46. Holmes, The Common Law 1 (1881). See also J. N. Frank, Courts on Triat 147 (1950); Stone, Fallacies of Logical Form in English Law, in Interpret.tTons of Modern Legal Philosophies 696 (1947).

47. Holmes, The Common Law 1 (1881); Justice Stone, dissenting (with Justices Brandeis and Cardozo) in Morehead v. New York ex rel. Tipaldo, 298 U.S. 587, 633 (1936). See Lincoln's statement that Supreme Court Justices "have, with others, the same passions for party, for power, and the privilege of their corps." Quoted in Ronels, op. cit. supra note 33, at 134. Justice Miller of the Supreme Court once said: "It is vain to contend with judges who have been, at the bar, the advocates of railroad companies, and all the forms of associated capital, when they are called upon to decide cases where such interests are in contest. All their training, all their feelings are from the start in favor of those who need no such influence." Id. at 146.

48. Hamilton, supra note 44, at 456; see J. N. Frank, Law and the Modern Mind 111 (1930).

49. See Freund, On Understanding the Supreane Court 3 (1949). See also PritChett, The Roosevelt CoURT xiii, 14, 282 (1948); Schlesinger, The Supreme Court: 1947, Fortune, Jan. 1947, p. 73.

50. This is true because the Constitution was "intended to endure for ages to come, and consequently to be adapted to the various crises in human affairs." Marshall, C.J., in McCulloch v. Maryland, 17 U.S. (4 Wheat.) *316, *415 (1819).

51. Jackson, The Supreme Court in the American System of Goverimanent 54 (1955). See also CURTIs, LIONs UNDER THE Throne, viii, 60-61 (1947).

52. See Frankfurter, The Supreme Court of the United States, in LAw and Pourtics 30 (1939). 
among his colleagues and the judges before whom he has appeared, the character of his clientele, and many other items that add up to the total of the technical ability he can bring to a judicial job. But even though the Supreme Court is an institution, an appointing President knows that individuals, with all their diversities of endowment, experience and outlook, determine its actions. ${ }^{53} \mathrm{He}$ therefore wisely looks far beyond the horizon of strictly legal capacity. He knows, with Chesterton, that the most important thing about a man is his philosophy. The determining factor is, and should be, the appointee's approach to, and attitude toward, the social and economic questions of the day.

Some Presidents have candidly revealed the considerations that guided them in selecting members of the Supreme Court. Lincoln once gave his reasons for appointing Chase as Chief Justice. One was Chase's large place in the public mind. Another was that "we wish for a Chief Justice who will sustain what has been done in regard to emancipation and the legal tenders. We cannot ask a man what he will do, and if we should, and he should answer us we should despise him for it. Therefore, we must take a man whose opinions are known."54 In a letter to Senator Lodge, Theodore Roosevelt gave the reasons why he was in favor of Justice Holmes. "The ablest lawyers and the greatest judges," he said, were men whose past "has naturally brought them into close relationship with the wealthiest and the most powerful clients," and Roosevelt was glad when he could find a judge like Holmes "who has been able to preserve his aloofness of mind so as to keep his broad humanity of feeling and his sympathy for the class from which he has not drawn his clients." "as Roosevelt went on to add that a judge of the Supreme Court should be neither "partisan" nor "politician" in the "ordinary and low sense" which we attach to these words. But "in the higher sense, in the proper sense," he should be "a party man, a constructive statesman, constantly keeping in mind his adherence to the principles and policies under which this nation has been built up and in accordance with which it must go on." "50 And Roosevelt wanted to know that Judge Holmes

53. See Frankfurter, Justice Holmes Defines the Constitution, in LAw AND Politics 62 (1939). Even Brandeis, according to his biographer, "was inclined by the pressures and drives of his own nature to translate his own economic and social views into the Constitution itself." Mason, ERandeis : A Free Man's Life 580 (1946).

54. 3 Warren, The Supreme Court in United States History 123 (1924). See also Gideon Welles' statement about Evarts as a possible appointee for the Supreme Court. Answering a question from Lincoln, Welles stated that Evarts was "among the foremost at the New York Bar." He then went on to say that that was not all : "Our Chief Justice must have a judicial mind, be upright, of strict integrity, not too pliant; should be a statesman and a politician." He then added that by "politician" he did not mean a "partisan." He meant one who was "impressed with the principles and doctrines which had brought this Administration into power"; it was all-important that Lincoln "should have a Judge who would be a correct and faithful expositor of the principles of his Administration and policy after his Administration shall have closed." Id. at 125-26.

55. Frinkfurter, Law and Politics 66 (1939).

56. Id. at 67 ; see 2 Pringle, The Life and Times of William Howard Taft 739 (1939). 
was "in entire sympathy with our views, that is, with your views and mine," before he would feel justified in appointing him. ${ }^{57}$

It was not wholly accidental that Wilson had an opportunity to appoint only three Justices in his eight years of presidency whereas Taft in his four years had appointed six members to the Court. In a candid newspaper conference held at the time Taft turned over the White House to Wilson in 1913, he said that he had told his appointees: "Damn you, if any of you die I'll disown you."פs Obviously, most of Taft's appointees took his threat to heart. Later, in the 1920 campaign, Taft urged the election of Mr. Harding on the ground that four of the incumbent Justices of the Supreme Court were beyond the retiring age of seventy, so that the next President would probably be called upon to appoint their successors. He urged that the election of Harding would help to insure the maintenance of the Supreme Court "as the bulwark to enforce the guaranty that no man shall be deprived of his property without due process of law." 59 Taft likewise saw the Court as a check on President Hoover, whom he suspected of liberal intervals. He once confessed that though he was "older and slower and less acute and more confused," he must stay on the Court as long as things continued as they were and he was able to answer in his place, "to prevent the Bolsheviki from getting control."

Political considerations of this kind are particularly relevant to appointments made during a period like the mid-thirties, and President Roosevelt might well have looked less to legal learning than to his version of wisdom in making the selections he made. Much of the legal learning of the past had crumbled before his eyes while he was in office. The education of most eligibles for the Court at that time had been acquired in large part in a past that was gone forever. It had been reversed by a powerful march of events that had swept away its foundations. It was dated. A new learning had to be assembled in a dazzling process of trial and error. At such a time a vested interest in obsolete legal learning might be a handicap to a new Justice on the Supreme Court. ${ }^{61}$ What was needed more than scholarship in any pedestrian sense of that term, and over and above strictly legal learning, was adaptability of attitude, a capacity for rapid assimilation of the lessons that violent experience was forcing upon

57. Frankfurter, Law and Politics 67 (1939); see 2 Pringle, op. cit. stpra note 56 , at 739 .

58. 2 PrINGLE, op. cit. silpra note 56 , at 854 .

59. Taft, Mr. Wilson and the Campaign, 10 Yale Rev. 1, 19-20 (1920).

60. 2 PRINGLE, op. cit. sutpra note 56, at 967. Cf. Wilson's letter to Justice Clarke, one of his appointees, when the latter resigned from the Court in 1922: "Like thousands of other liberals throughout the country, I have been counting on the influence of you and $J$ ustice Brandeis to restrain the Court in some measure from the extreme reactionary course which it seems inclined to follow ... . The most obvious and immediate danger to which we are exposed is that the courts will more and more outrage the common people's sense of justice and cause a revulsion against judicial authority which may seriously disturb the equilibrium of our institutions, and I see nothing which can save us from this danger if the Supreme Court is to repudiate a liberal course of thought and action."

61. Cf. McCune, The Nine Young Men 46 (1947). 
puzzled minds, and a mature acceptance of life in a chaotic new world that had replaced the world in which most existing legal learning had developed.

\section{Stare Decisis in a Brave New World}

Justice Black's concurring opinion in Helvering v. Gerhardt, ${ }^{62}$ decided shortly after he joined the Court, was truly what Chief Justice Hughes in speaking of dissents had called "an appeal to the brooding spirit of the law, to the intelligence of a future day." 63 It gave early proof that Justice Black was not the kind of judge "to deny the reality of change" or to "conceal the truth of adaptation behind a verbal disguise of fixity and universality." ${ }_{4}$ Rather he would, in the democratic tradition, choose the principle of blunt, open and direct disclosure. ${ }^{05}$ Black's Gerhardt opinion furnished as well an indication of his attitude toward stare decisis.

The Gcrhardt case involved the constitutional power of the federal government to impose income tax upon salaries received by employees of the Port of New York Authority, a bi-state corporation created by compact between New York and New Jersey to operate transportation facilities between the two states. The taxpayers relied principally upon McCulloch $v$. Maryland ${ }^{66}$ and Collector $v$. Day. ${ }^{67}$ In the former case Chief Justice Marshall's opinion invalidated a state tax upon national banks. In the latter the Court held that the salary of a state probate judge was immune from the federal income tax.

Justice Stone, as spokesman for the Court in upholding the challenged tax, composed the cautious, compromise type of opinion that would satisfy some other Justices by hiding innovation "behind a formal distinction." himself equal to the dexterous task of sustaining the tax without overruling Collcctor $v$. Day. He accomplished this objective by distinguishing and limiting that case, giving it lip service but confining its message to its particular facts." Collector $v$. Day had involved a tax upon the salary of an officer "engaged in the performance of an indispensable function of the state which cannot be delegated to private individuals." 70 But the tax challenged in the Gerhardt case neither precluded nor threatened "unreasonably to obstruct any

62. 304 U.S. 405, 424 (1938). For a discussion of this case, see Pritchetr, The Roosenelt Coutr 61 (1948).

63. Hughes, The Supredre Court of the United States 68 (1928). As to the function of dissents, and sometimes of separate concurring opinions, see Powell, And Repent at Lcistrere, 58 Harv. L. Rev. 930, 943 (1945) ; Pritchett, The Roosevelt Court 50 (1948);

Hamilton, supra note 44 , at 455 .

64. J. N. Frank, Law and the Modern Mind 293 (1930).

65. Cf. Douglas, supra note 44 , at 754 .

66. 17 U.S. (4 Wheat.) *316 (1819).

67. 78 U.S. (11 Wall.) 113 (1871).

68. Hamilton, supra note 44, at 453. See also id. at 455; Cardozo, Law and Literature, 14 Yale L.J. 699, 715 (1925) ; Pritchett, The Roosevelt Court 51 (1948).

69. Cf. J. N. Frank, Courts on Trial 275 (1950); Llewellyn, The Brantble Bush $63(1930)$.

70. Helvering v. Gerhardt, 304 U.S. 405, 424 (1938). 
function essential to the continued existence of the state government."71 So much of the burden of the tax laid upon the taxpayer's salary as might reach the state was "but a necessary incident to the co-existence within the same organized government of the two taxing sovereigns," and hence was a burden contemplated by the Constitution. ${ }^{\mathbf{2}}$

While Justice Black agreed that the payment of a nondiscriminatory federal income tax on their salaries by employees of the Port of New York Authority would not impair or defeat the governmental operations of the State of New York, he was unable to reconcile the majority opinion with the principle announced in Collector v. Day and later opinions applying that principle. To him the rule established by the majority opinion made the tax status of every state employee uncertain until the Supreme Court passed upon the classification of his particular employment, and created a "confusion in the field of inter-governmental tax immunity" which the new Justice believed could be "clarified by complete review of the subject." 73 The uncertainty and inequality of treatment created by the test was manifest: there might be a tax upon the income of an officer of a state-operated transportation system but none upon the income of the manager of a municipal water works system.

In Black's view the Gerhardt case afforded an appropriate occasion for a thorough re-examination of the rule of Collector $v$. Day. His opinion ended with these two paragraphs:

"There is not, and there cannot be, any unchanging line of demarcation between essential and nonessential governmental functions. Many governmental functions of today have at some time in the past been non-governmental. The genius of our government provides that, within the sphere of constitutional action, the people-acting not through the courts but through their elected legislative representatives-have the power to determine as conditions demand, what services and functions the public welfare requires.

"Surely, the Constitution contains no imperative mandate that public employees-or others-drawing equal salaries (income) should be divided into taxpaying and non-taxpaying groups. Ordinarily such a result is discrimination. Uniform taxation upon those equally able to bear their fair shares of the burdens of government is the objective of every just government. The language of the Sixteenth Amendment empowering Congress to 'collect taxes on incomes, from whatever source derived'-given its most obvious meaning - is broad enough to accomplish this purpose."7t

Further re-examination of the doctrine of Collector $v$. Day came more promptly than Justice Black could have anticipated. Within two years the case was explicitly overruled insofar as it recognized "an implied constitutional immunity from income taxation of the salaries of officers or employees of a national or a state government or their instrumentalities." 75

71. Ibid.

72. Ibid.

73. Id. at 426.

74. Id. at 427 .

75. Graves v. New York ex rel. O'Keefe, 306 U.S. 466, 486 (1939). See JACKsoN, The Struggle For J Udictal SUPREMaCy 243 (1941). 
Black's concurring opinion in the Gerhardt case illustrated at an early date a basic attitude of Roosevelt's first appointee to the Court. It was incumbent upon the Court, in his view, to face constitutional issues squarely. Obsolete doctrines should be abandoned "openly and avowedly." The interpretation of the Constitution should move forward with changing times. ${ }^{77}$ Its dynamic march should not be obstructed by an unwillingness to overrule precedents simply because they were hallowed with age. The Court must bow "to the lessons of experience and the force of better reasoning, recognizing that the process of trial and error, so fruitful in the physical sciences, is appropriate also in the judicial function."78

The rule of stare decisis has "only a limited application in the field of constitutional law."78 It has more potency in cases where correction can be achieved through legislation than in those involving the Constitution, where correction is only possible through the laborious process of amendment. ${ }^{80}$ But "legislative correction of judicial errors is often difficult to effect,"'s1 and the courts must occasionally take a hand in dispelling error that they have themselves produced. So in Commissioner v. Estate of Church ${ }^{82}$ Justice Black spoke for a majority of the Court in stating that the policy of stare decisis and "an alleged interest in stability and certainty" $\$ 3$ should not prevent the Court from overruling its decision in May $v$. Heiner, ${ }^{84}$ handed down eighteen years previously and reaffirmed in three per curiam decisions joined in by Chief Justice Hughes and Justices Holmes, Brandeis and Stone. ${ }^{85}$

The Church case involved the interpretation of that part of section 811 (c) of the 1939 Internal Revenue Code which required the inclusion in a decedent's gross estate of the value of all property the decedent had transferred to a trust "intended to take effect in possession or enjoyment at or after his death."'86

76. Douglas, J., dissenting (with Black, J.) in Commissioner v. Harmon, 323 U.S. 44, 49, 57 (1944); cf. the Black dissent in McDonald v. Commissioner, 323 U.S. 57, 65 (1944).

77. See J. P. Frants, Mr. Justice Black, The Man and Hrs Opinrons 109 (1949).

78. Brandeis, J., dissenting in Burnet v. Coronado Oil \& Gas Co., 285 U.S. 393, 407-08 (1932). Justice Brandeis' protest in this case was a fruitful one. See Helvering v. Mountain Producers Corp., 303 U.S. 376 (1938) ; Oklahoma Tax Comm'r v. United States, 319 U.S. 598 (1943).

79. Douglas, J., dissenting (with Black, J.) in New York v. United States, 326 U.S. $572,590(1946)$. On the subject of stare decisis in general, see Douglas, supra note 44; J. N. FRank, Courts on TRIal 262 (1950).

80. See Burnet v. Coronado Oil \& Gas Co., 285 U.S. 393, 406-07 (1932) (Brandeis, J., dissenting opinion). See also Curtis, Lions Under the Throne $56-57$ (1947).

81. Douglas, supra note 44 , at $746-47$; cf. FREUND, op. cit. supra note 49 , at 38 .

82. 335 U.S. 632 (1949).

83. Commissioner v. Estate of Church, 335 U.S. 632, 647 (1949).

84. 281 U.S. 238 (1930).

85. Burnet v. Northern Trust Co., 283 U.S. 782 (1931) ; Morsman v. Burnet, 283 U.S. 783 (1931); McCormick v. Burnet, 283 U.S. 784 (1931).

S6. Int. Rev. Code of 1939, 53 Stat. 1. See also Estate of Spiegel v. Commissioner, 335 U.S. 701 (1949), involving the interpretation of the same provision with reference to a trust with a possibility of reverter. 
The question was whether property in a trust was includible in the taxable estate of its grantor because of a clause reserving its income to the grantor for life. Against the strong trend of previous authority, the Supreme Court had held in May v. Heiner that the property was not to be included. After the reaffirmation of this astonishing ruling in the per curiam decisions referred to, ${ }^{87}$ Congress had promptly responded with a joint resolution ${ }^{8 s}$ providing for the inclusion of the property of such a trust in the grantor's estate, and this joint resolution had been incorporated in the 1932 Act, ${ }^{89}$ at least as to trusts created after the passage of the resolution. ${ }^{00}$ The trust in the Church case had been set up before the resolution; and so the vitality of May $v$. Heiner was still in question. Justice Black's majority opinion held that May $v$. Heiner should no longer be accepted as a controlling interpretation of the "possession or enjoyment" clause of section 811 (c) because Helvering v. Hallock" "directly and unequivocally rejected the only support that could possibly suffice" for what the Court held in May' $v$. Heiner. ${ }^{92}$ Speaking of a transfer in trust with a reservation of a life interest, he wrote:

"How is it possible to call this trust transfer 'complete' except by invoking a fiction? Church was sole owner of the stocks before the transfer. Probably their greatest property value to Church was his continuing right To get their income. . . . That property right did not pass to the trust beneficiaries when the trust was executed: it remained in Church until he died. He made no 'complete' gift effective before that date, unless we view' the trust transfer as a 'complete' gift to the trustees. But Church gave the trustees nothing, either partially or completely. He transferred no right to them to get and spend the stock income. And under the teaching of the Hallock case, quite in contrast to that of May v. Heiner, passage of the mere technical legal title to a trustee is not necessarily crucial in determin-

87. See cases cited note 85 supra.

88. Resolution of March 3, 1931, c. 452, 46 Stat. 1516. See Rodell, Nine Men: A Poldtical History of the Supreme Court from 1790 to 1955, at 37 (1955).

89. Revenue Act of 1932, $\$ 302$ (c), 47 Stat. 279.

90. Hassett v. WeIch, 303 U.S. 303 (1938).

91. 309 U.S. 106 (1940), overruling Helvering v. St. Louis Union Trust Co., 296 U.S. 39 (1935), and Becker v. St. Louis Union Trust Co., 296 U.S. 48 (1935). The taxpay'r in the Hallock case had created a trust providing that the income from the trust propurty should be paid to his wife during her lifetime; that upon his death, if she survived him, the corpus of the trust should go to her or other named beneficiaries, but that upon her death, if he survived, the property should revert to himself. The wife survived. The cass held, briefly, that the value of the remainder interest should be included in the decedent's gross estate as a transfer intended to take effect in possession or enjoyment at or after the grantor's death. The Hallock decision is ably discussed in Eisenstein, The Hallock Prohlemb: A Case Study in Administration, 58 Harv. L. Rev. 1141 (1945).

92. Commissioner v. Estate of Church, 335 U.S. 632, 643 (1949). Justice Black refused to accept the argument that the error of lfay $v$. Heiner should be continued because of Treasury regulations which had accepted that decision, and the argument that Congress had ratified the doctrine of the case when it passed the Joint Resolution. He also found no merit in the contention that subsequent cases set at rest all questions as to the soundness of the May v. Heiner interpretation. See also Commissioner v. Hall's Estate, 153 F.2d 172, 174 (2d Cir. 1946) (Frank, J., dissenting opinion). 
ing whether and when a gift becomes 'complete' for estate tax purposes. Looking to substance and not merely to form, as we must unless we depart from the teaching of Hallock, the inescapable fact is that Church retained for himself until death a most valuable property right in these stocks-the right to get and to spend their income. Thus Church did far more than attach a 'string' to a remotely possible reversionary interest in the property, a sufficient reservation under the Hallock rule to make the value of the corpus subject to an estate tax. Church did not even risk attaching an unbrealsable cable to the most valuable property attribute of the stocks, their income. He simply retained this valuable property, the right to the income, for himself until death, when for the first time the stock with all its property attributes 'passed' from Church to the trust beneficiaries. Even if the interest of Church was merely 'obliterated,' in May v. Heiner language, it is beyond all doubt that simultaneously with his death, Church no longer owned the right to the income; the beneficiaries did. It had then 'passed.' It never had before. For the first time, the gift had become 'complete." "03

Justice Frankfurter, who had written the Hallock majority opinion, disagreed sharply with Justice Black's majority opinion in the Church case. $\mathrm{He}$ thought that it reflected an inappropriate attitude toward a series of long standing unanimous decisions of the Court, and too little respect for the expressed intention of Congress. To him, also, stare decisis was not "a universal, inexorable command," but neither was it "a doctrine of the dead hand." It made a difference to him, as it did not to Justice Black, that the Court was not dealing in the Church case with "a ruling which cramps the power of government," or with "a constitutional adjudication which time and experience have proved a parochial instead of a spacious view of the Constitution and which thus calls for self-correction by the Court without waiting for the leaden-footed process of constitutional amendment"; that the Court was dealing, rather, with an exercise of the Court's "duty to construe what Congress has enacted with ample powers on its part quickly and completely to correct misconstruction."

It required about 55,000 words to express the divergent views of the various members of the Supreme Court in the Church case and its companion, the Spiegel case. ${ }^{96}$ Despite this "outbreak of . . explanation," the blood pressure of the tax bar rose to a new high if for no other reason, Adrian DeWind has explained, ${ }^{97}$ than the short shrift the decision gave to the doctrine of stare decisis as a protection for entrenched interest in error. The Treasury, discreetly feeling that it had won too much for its own comfort, decided that the early error of the Supreme Court was too deeply embedded in tax law to be fully corrected immediately. Accordingly, the Treasury partially reinstated the earlier overruled doctrine of the Supreme Court, by a regulation that made the new cor-

93. Commissioner v. Estate of Church, supra note 92, at 644-45.

94. Id. at 676 .

95. Id. at 676-77.

96. Estate of Spiegel v. Commissioner, 335 U.S. 701 (1949). See note 86 supra.

97. DeWind, Federal Estate and Gift Taxation, in 1949 Annual Survey of American LAw 225, 226 (1949). 
rect doctrine inapplicable to the estates of decedents dying before January 17 , 1949,98 the date of the Church decision. An even more generous Congress quickly granted further relief. In the Technical Changes Act of $1949^{\circ 0}$ it extended to January 1, 1950, the immunity granted by the Treasury in its amended regulation. The theory was that some months would be needed to relinquish or assign the life estates which condemned entire estates to the impact of the estate tax..$^{100}$ Under this provision the new rule established by the Church case would apply only to decedents dying after December 31,1949 . In addition, the statute allowed a further period in which to transfer or relinquish the tainted life interests. Transfers in 1949 and 1950 escaped gift tax; transfers in 1949 escaped the possibility of the charge that they were made in contemplation of death; and transfers in 1951 and later years were to be subject to the gift tax and the possibility of estate taxation if they were found to have been made in contemplation of death. The Technical Changes Act of 1949 also expressed disapproval of the Supreme Court decision in the Spiegel case. ${ }^{101}$

\section{Tax Avoidance in Later Manifestatron}

Tax law has its share of "seductive clichés"102 and verbalistic distinctions. One of the most overworked distinctions in tax opinions and briefs contrasts the vague alternatives "form" and "substance"-terms which Judge Learned Hand has called "anodynes for the pains of reasoning." 103 Though they are sometimes useful as terms of general contrast, these favorite "catch words and labels" are "subject to the dangers that lurk in metaphors and symbols, and must be watched with circumspection lest they put us off our guard."104 One test of a judge is whether he succumbs to the dangers against which Justice Cardozo thus wisely warned us. And so the question may be asked whether Justice Black is a cliché thinker, who lets himself be led astray by these and other semanticisms of tax lawyers.

It is true that "form" and "substance" are words which appear with reasonable frequency in opinions written by Justice Black in the field of taxation. "The incidence of taxation depends," he has said, "upon the substance of a trans-

98. U.S. TREAS. REG. 105, $\$ 81.17$ (1949), as amended, T.D. 5741, 1919-2 CUM. BuLL. 114.

99. 63 Stat. 894.

100. The action of Congress in 1949 has been described by Professor Boris Bittker of the Yale Law School as being based upon the theory that many persons who established trusts relied upon the incorrect decision in May v. Heiner, and that the later decision correcting the error of the earlier decision "disappointed their reasonable expectations"-principally their expectation that the error would be perpetuated for all time. Bittker, Chutrch and Spiegel: The Legislative Sequel, 59 Y ALE L.J. 395, 414 (1950).

101. See Paul, Taxation in the United States 533 (1954).

102. Grave's v. New York ex rel. O'Keefe, 306 U.S. 466, 489 (1939).

103. Commissioner v. Sansome, 60 F.2d 931, 933 (2d Cir.), cert. denied, 287 U.S. 667 (1932). Cf. Cardozo, Law and Literature 5 (1931); Sage v. Commissioner, 83 F.2d 221, 224 (2d Cir. 1936).

104. Cardozo, J., in Hanneford v. Silas Mason Co., 300 U.S. 577, 586 (1937). 
action."105 "In the field of taxation, administrators of the laws, and the courts, are concerned with substance and realities, and formal written documents are not rigidly binding." 106 The question in tax cases is whether a gain is "real and substantial."107 "The essence of a gift by trust is the abandonment of control over the property put in trust," and it is important to note that the grantor "has neither the form nor substance of control."108 "Bookkeeping devices and paper contrivances should not be permitted to make two payments out of one," and the tax statutes do not compel the conclusion that Congress "intended to reward ingenuity in paper work by granting multiple tax reductions for a single money payment to discharge a single corporate obligation."109 The Supreme Court "must not give effect to any contrivance which would defeat a tax Congress plainly intended to impose. The use of bookkeeping and accounting forms and devices cannot be permitted to devitalize valid tax laws." 110

These quotations suggest the flavor of Justice Black's basic approach to tax law. It is to his credit, however, that he is never content to let his opinions rest upon sweeping generalizations. Fully aware that "general propositions do not decide concrete cases,"111 he puts general terms such as "form" and "substance" in the context of careful factual accounts of transactions. In the Court Holding case ${ }^{112}$ the facts showed that the sale of corporation property by stoclkholders was, as the Tax Court had found, "in substance the sale of the corporation," 113 and Justice Black held for the Court that it should be taxed as such. But it did not follow in Justice Black's mind that there could be no escape from corporate tax if there was a genuine liquidation and distrihution and the stockholders were more than mere conduits through which to pass title. The $C u m b e r l a n d$ case ${ }^{114}$ brought to the Court a transaction in which the lower court had found that there had been a genuine liquidation. In this case the Cumberland Company stockholders offered to sell all their stock to a competing co-operative. The co-operative refused to buy the stock, but countered with an offer to buy the transmission and distribution equipment of the Cumberland Company. At the same time the Cumberland shareholders, desiring to escape payment of the corporate capital gains tax, offered to acquire the equipment and sell it to the co-operative. The co-operative accepted; the corporation transferred the equipment to its shareholders in partial liquidation; after a sale of remaining assets the corporation was dissolved. The shareholders

105. Commissioner v. Court Holding Co., 324 U.S. 331, 334 (1945).

105. Helvering v. F. \& R. Lazarus \& Co., 308 U.S. 252, 255 (1939).

107. United States v. Hendler, 303 U.S. 564, 566 (1938).

108. Snith v. Shaughnessy, 318 U.S. 176, 181 (1943).

109. Helvering v. Sabine Transp. Co., 318 U.S. 306, 312 (1943) (dissenting opinion).

110. Foster v. United States, 303 U.S. 11S, 121 (1938).

111. Holmes, J., dissenting, in Lochner v. New York, 198 U.S. 45, 76 (1905); see letter from Oliver Wendell Holmes to Dr. Wu, June 16, 1923, in Justuce Oltver Wenderz Holmes, His Bcok Notices and Uncollected Letters and Papers 164-65 (1936).

112. Court Holding Co., 2 T.C. 531, 539 (1943).

113. Commissioner v. Court Holding Co., 324 U.S. 331, 334 (1945).

114. United States v. Cumberland Pub. Serv. Co., 338 U.S. 451 (1950). 
then executed the previously contemplated sale to the co-operative. To the government this looked like another Court Holding case. But not to Justice Black. A corporation cannot be taxed "when the sale has been made by its stockholders following a genuine liquidation and dissolution," even though "a major motive of the shareholders was to reduce taxes."115 The motive of the shareholders was relevant in determining whether the transaction was "real or a sham," but sales of physical property following a genuine liquidation distribution cannot "be attributed to the corporation for tax purposes."116

In working his way to this conclusion the Justice was perfectly aware of the shadowy and artificial character of the distinction between sales by a corporation and shareholder sales after a distribution in kind. But Congress had chosen to recognize the distinction, and the Court was bound to follow the mandate of Congress that different tax consequences should "flow from different methods by which the shareholders of a closely held corporation may dispose of corporate property." 117

The Cumberland opinion of Justice Black, like many other tax opinions of the Supreme Court, had a legislative sequel. ${ }^{118}$ In the new and much publicized 1954 Code Congress made a valiant attempt to eliminate the oddities of tax consequences that emerge from different ways of selling the assets of liquidating corporations. ${ }^{119}$ Whether this part of an ambitious attempt to make tax law "simpler and surer" 120 will prove successful without amendatory legislation is one of the many things in tax law that remain to be seen. ${ }^{121}$

115. Id. at 454-55.

116. Ibid.

117. Id. at 456 .

118. E.g., Lykes v. United States, 343 U.S. 118 (1952) (overruled by INT. REv. CoDE of 1954, $\S 212(3)$ ) ; United States v. Lewis, 340 U.S. 590 (1951) (changed by INT. Rev. CODE of 1954, § 1341) ; Bazley v. Commissioner, 331 U.S. 737 (1947) (clarified by INT. REv. CODE of 1954, \$ 306); Commissioner v. Smith, 324 U.S. 177 (1945) (modified by Int. Rev. Code of 1939, $\$ 130 \mathrm{~A}$, added by 64 Stat. 942 (1950), now Int. Rev. CodE or 1954, § 421) ; Magruder v. Supplee, 316 U.S. 394 (1942) (changed by INT. Rev. CodE or 1954, $\$ 164(d)$ ) ; Higgins v. Commissioner, 312 U.S. 212 (1941) (overruled by Int. Rev. Code of 1939, $\$ 23$ (a) (2), 53 Stat. 12, now INr. Rev. Code of 1954, \$ 212); Helvering v. Bruun, 309 U.S. 461 (1940) (overruled by Int. Rev. Code of 1939, $\$ 22($ b) (11), added by 56 Stat. 812 (1942), now INT. REv. CODE of 1954, § 109); Helvering v. Clifford, 309 U.S. 331 (1940) (partially incorporated in INT. REv. CoDE of 1954, $\$ \$ 671-78$ ) ; United States v. Hendler, 303 U.S. 564 (1938) (overruled by Int. Rev. Code of 1939, $\$ 22$ (b) (9), added by 56 Stat. 811 (1942), now Int. Rev. CODE of 1954, $\$ 108$ ); Helvering v. Bashford, 302 U.S. 454 (1937) ; Groman v. Commissioner, 302 U.S. 82 (1937) (overruled by INT. Rev. CODE of 1954, § 368); Koshland v. Helvering, 298 U.S. 441 (1936) (changed by INT. Rev. ConE of 1954, § 305); General Util. \& Operating Co. v. Helvering, 296 U.S. 200 (1935) (incorporated in INT. REv. CoDE OF 1954, \$ 311).

119. INT. Rev. CoDE of 1954, § 337.

120. President Eisenhower's Budget Message, Jan. 21, 1954. 100 Cong. Rec. 540 (1954).

121. I think that the Congress tried to do too much too quickly in the 1954 Code. The resulting legislation is so complicated that the experts in the Treasury have had a difficult time assembling regulations covering parts of the Code. The Hegelian product of this 
The Court Holding and Cumberland cases edge into the controversial field of tax avoidance. One of the principal devices of the thirties and later years for the minimization of family tax liability was the family partnership. ${ }^{122}$ It is customary for taxpayers to rely in tax avoidance cases upon the shopworn principle that they have a "legal right" to avoid taxes by means which the law permits. ${ }^{123}$ But tax avoidance is one part of tax law that has brought home to many taxpayers the grim lesson that general abstract propositions do not decide particular cases. This was the first lesson to be learned from two of Justice Blacls's opinions dealing with family partnerships-the Tower ${ }^{124}$ and Lusthaus ${ }^{125}$ cases. The next decision, in the Culbertson case, ${ }^{126}$ should have taught the Treasury the equally important lesson that it is dangerous to overplay victory, for the Treasury was less successful in its second round in the Supreme Court on the family partnership problem.

The Tower and Lusthaus cases involved a family partnership device that created "an acute problem" for the tax collector in the late thirties and the forties. ${ }^{127}$ The facts of the Tower case sufficiently illustrate the conventional pattern of the device. For nearly thirty years the taxpayer had done a manufacturing business in Michigan. From 1933 to 1937 the business was operated as a corporation. The taxpayer was president of the corporation and owned almost all of the outstanding shares of stock; his wife was vice president and owned a few shares. The wife was on the board of three directors, along with her husband and a bookkeeper who also owned a few shares. The husband managed the corporate affairs; the wife performed no business services.

In 1937, when substantial profits pointed to increased taxes, the taxpayer's attorney and his tax accountant advised him that the dissolution of the corporation and the formation of a partnership would save taxes and eliminate the necessity of filing corporate returns. Acting upon this advice, the taxpayer transferred a block of stock to his wife on condition that she place the corporate assets represented by the transferred shares in a new partnership. This she did three days after the stock transfer. The husband paid a small gift tax on the transfer of the shares to the wife. The wife became a limited partner in the new partnership. A certificate of partnership was filed as required by Michigan law. The formation of the partnership did not in any way alter the conduct of

fabulous burst of legislative energy brings to mind Judge Learned Hand's famous protest arainst the passionate rationality of tax statutes. The 1954 Code is truly a "monster." It $s$ words, it is true, are "strung together with syntactical correctness"; its meaning is another matter. The process of its interpretation will certainly require "the most inordinate expunditure of time" on the part of taxpayers, tax experts, administrative authorities, and the courts. Sec Hand, Thomas Walter Swan, 57 YALE L.J. 167, 169 (1947).

122. See Paul, Partnerships in Tax Avoidance, 13 Geo. Wash. L. Rev. 121 (1945).

123. See Gregory v. Helvering, 293 U.S. 465, 469 (1935); United States v. Isham, \&4 U.S. (17 Wall.) 496 (1873).

124. Commissioner v. Tower, 327 U.S. 280 (1946).

125. Commissioner v. Lusthaus, 327 U.S. 293 (1946).

126. Commissioner v. Culbertson, 337 U.S. 733 (1949).

127. See Paul, Partnerships in Tax Avoidance, 13 Geo. WAsh. L. Rev. 121 (1945). 
the business $:^{128}$ the husband continued to have the controlling voice as to purchases, sales, salaries, the time of distribution of income, and all other essentials. The wife used her drawings from the partnership to buy "what a husband usually buys for his wife such as clothes and things for the family or to carry on activities ordinarily of interest to the family as a group."129

In Justice Black's majority opinion these facts were sufficient to support the Tax Court's finding that for tax purposes the wife was not a partner in the business. The validity of the partnership under Michigan law did not make it "a real partnership" under federal tax law. "The simple expedient of drawing up papers" was not enough to divide "single tax earnings" into "two tax units" for purposes of a tax law that looks to command of the taxpayer over income and seeks to tax income to the person who earns it. ${ }^{130}$ The creation of the partnership did not change the economic relation of the husband and wife to the income of the business. After the creation of the partnership, as before, the husband managed and controlled the business; neither before nor after did the wife contribute services or take part in the management. After the creation of the partnership the wife used the income attributed to her only for the purpose of buying the type of things she had bought for herself, the home and the family before the partnership was formed. "Consequently the result of the partnership was a mere paper reallocation of income among the family members," and there was more than ample evidence to support the Tax Court's finding that no genuine union for partnership business purposes was ever intended, and that the husband earned the income. ${ }^{131}$

The Court did not reject the principle that taxpayers have a right to avoid taxes by legal means. That principle would apply, Justice Black's majority opinion stated, in "a situation where a member of a partnership, in order to keep from paying future taxes on partnership profits and in order to get into a lower income tax bracket sells his interest to a stranger, relinquishing all control of the business." 132 The principle did not apply where the taxpayer

"draws a paper purporting to sell his partnership interest even to a stranger, though actually he continues to control the business to the extent he had before the 'sale' and channels the income to his wife. Then a showing that the arrangement was made for the express purpose of reducing taxes simply lends further support to the inference that the husband still controls the income from his partnership interest, that no partnership really exists, and that the earnings are really his and are therefore taxable to him and not to his wife. The arrangement we are here considering was of the type where proof of a motive to reduce income taxes simply lent further strength to the inference drawn by the Tax Court that the wife

128. But "both Amidon [the secretary] and Tower ceased to draw salaries." Commissioner v. Tower, 327 U.S. 280, 286 (1946).

129. $I d$. at 286 .

130. Id. at 291 .

131. $I d$. at 292.

132. Id. at $288-89$. 
was not really a partner. . . To rule otherwise would mean ordering the Tax Court to shut its eyes to the realities of tax avoidance schemes."133

In the Culbertson case ${ }^{134}$ Chief Justice Vinson made a courageous, but unsuccessful, effort to clarify a difficult subject which Justice Black's opinions in the Tower and Lusthaus ${ }^{135}$ cases had left in considerable obscurity. Culbertson for many years had operated a cattle business in partnership with a man named Coon. Coon, who was seventy-nine years old in 1939, wished to dissolve the partnership because of ill-health. The greater part of the partnership herd was sold, but Culbertson wished to keep about 1,500 Herefords, the brood or foundation herd. He offered to buy these cattle, and Coon agreed on condition that Culbertson would sell an undivided one-half interest in the herd to Culbertson's four sons at the same price. Coon's reasons for exacting this condition were his interest in maintaining the Hereford strain, his conviction that Culbertson was too old to carry on the work alone, and his personal interest in the Culbertson boys. The boys paid for their interests largely with notes and partly with the proceeds of a gift from Culbertson. The old partnership was dissolved. A new oral partnership continued the business.

The four Culbertson boys were young when the new partnership began business. The oldest boy, twenty-four years old, was married and lived on the ranch. A college graduate, he had been foreman for two years under the old partnership. He received $\$ 100$ a month plus board and lodging for himself and his wife, both before and after the new partnership was organized, and until he entered the Army. The second boy was twenty-two years old and married. He finished college during the first year of the new partnership, and then went directly into the Army following graduation and rendered no services for the partnership. The two younger sons were eighteen and sixteen years old, respectively. They went to school during the winter and worked on the ranch during the summer.

The principal factual difference between the Tower and Lusthaus cases on the one hand and the Culbertson case on the other was that a tax avoidance motive reared its ugly head in the former cases and seems to have been absent from the latter. ${ }^{130}$ Perhaps this is the "inarticulate major premise" of any retreat which may have been made by the Court in the later case. ${ }^{137}$ It must be

133. Id. at $2 S 9$.

134. Commissioner v. Culbertson, 337 U.S. 733 (1949).

135. In the Lutsthaus case the taxpayer owned and operated a retail furniture business with two stores. His wife helped in the stores when needed without compensation. In order to reduce taxes, taxpayer sold a half interest in the business to his wife and executed a partnership agreement. The wife continued to help out when needed but the taxpayer retained full control of the business. The Court held that the evidence was sufficient to support a finding by the Tax Court that there was no genuine partnership.

136. Commissioner v. Culbertson, 337 U.S. 733, 738 (1949).

137. This premise was, however, disclaimed by the Chief Justice in his majority opinion in the Culbertson case. Ibid. And he and Justice Reed had dissented in the Tozver and Lusthaus cases. 
admitted in any event that the total interpretation furnished by the three cases left something to be desired which has not yet been supplied. Justice Black's earlier opinions seemed to some lawyers and judges to make the tax validity of a family partnership depend upon either the contribution of original (not donated) capital or the performance of services by the wife. But in the Culbertson case the Court said that the use of these tests by the Tax Court was "at best, an error in emphasis."138 The test is rather whether the partnership is "real," whether "the parties in good faith and acting with a business purpose intended to join together in the present conduct of the enterprise."139 Thus the Court seemed to establish an "intention" test, making the validity of a fanily partnership depend upon subjective considerations. ${ }^{140}$

Congress with some justification thought that the Tower, Lusthaus and $\mathrm{Cul}$ bertson cases had produced "confusion." 141 Whether its remedy is worse than the disease remains to be seen. In any event, in the 1951 Act it amended the Code to wipe out the "intention" criterion set up by the Culbertson opinion and the factual standards set up by the Tower and Lusthaus opinions. ${ }^{142}$ Under the new provisions, which have been incorporated in the 1954 Code, ${ }^{143}$ a partnership capital interest will be recognized even though it was acquired by purchase or gift from any other person, including a member of the family. Where a capital interest has been acquired by gift, the distributable share of the donee partner under the partnership agreement must be included in the donee's gross income "except to the extent that such share is determined without allowance of reasonable compensation for services rendered to the partnership by the donor, and except to the extent that the portion of such share attributable to the donated capital is proportionately greater than the share of the donor attributable to the donor's capital." 144 The distributive share of a partner in the earnings of a partnership cannot be diminished because of absence due to military service.

This legislative solution can hardly be regarded as ideal. Since the adoption of income-splitting for husband and wife in 1948, the problem has narrowed to one involving child partners, or partnerships with trustee nembers. ${ }^{115} \mathrm{~A}$ partnership consisting of a father and a business acquaintance trustee for a minor son has been recognized. ${ }^{146}$ A trust of which a father-partner is trustee

138. Commissioner v. Culbertson, 337 U.S. 733, 741 (1949). Or, less politely, "an erroneous reading of the Tower opinion." Id. at 745 .

139. Id. at 742 .

140. See Comment, Family Partnerships and the Revenue Act of 1951,61 YalE L.J. $5+1$ (1952). See also Lifton, The Family Partnership: Here Wc Go Again, 7 TAx L. Rev. 461 (1952); Schulman, Current Tests for Valid Family Partnership Arrangenents, 31 TAXES 447 (1953).

141. S. Rep. No. 781, 82d Cong., 1st Sess. 39 (1951).

142. Int. Rev. Code of 1939, \& 3797 (a) (2), as amended, 65 STAT. 511 (1951).

143. Int. Rev. CoDE of 1954, $\$ \$ 704$ (e), 7701 (a) (2).

144. Id., $\$ 704(\mathrm{e})(2)$.

145. Int. Rev. Code of 1939, \& 51(b), as amended, 62 Stat. 115 (1948) (now Int. Rev. Code of 1954, \$ 6013). See Paul, Taxatron in the United States $482-83$ (1954). 146. Louis R. Eisenmann, 17 T.C. 1426 (1952). 
may be a limited partner ;147 so may a third party trustee for a minor son of the settlor-partner. ${ }^{148}$ But it has also been held that there is no valid partnership for tax purposes where the partner-trustee for a minor son was first a physician who had nothing to offer the business and later one of the other partners. ${ }^{140}$ On the other hand, two men who placed their partnership interests in trust for a mother and wife respectively, and then ran the business as trustees, have been treated as partners. ${ }^{150}$

These attempted solutions in particular cases of the complex problem of family partnerships have in them a sardonic humor which suggests that subtleties have not been completely eliminated from the tax scene. Humor of a lighter character may also be admitted to the premises. In their income tax casebook Surrey and Warren tell of one case in which partnership agreements were prepared with the name of the new partner left blank "awaiting his expected birth so that sex and name could then be supplied."151 They also call attention to the case of Redd $v$. Commissioner, ${ }^{152}$ involving as partners a husband, a wife, and four children aged seven, five and two years, and three months, respectively. On the trial of this case the partner's wife testified as follows:

"Q. Now, do you participate in the management of the business of the LaSalle Livestock Company?

"A. Well, I have been producing partners.

"Q. Beg pardon.

"A. I have been too busy producing partners, so far."153

Similarly, tax lawyers are still busy producing family partnerships with infant members.

It might have been better if the Courts and Congress had adopted a Clifford ${ }^{154}$ approach to this elusive problem. In his Tower opinion Justice Black did mention the Clifford case for the point that the purpose of the tax statute to tax all income to the person who controlled its distribution could not be frustrated by family group arrangements, even though the arrangements were valid for state law purposes; and for the point that "transactions between husband and wife calculated to reduce family taxes should always be subjected to special scrutiny."155 And in the Culbertson case Chief Justice Vinson cited the

147. Theodore D. Stern, 15 T.C. 521 (1950).

148. Edward D. Sultan, 18 T.C. 715 (1952).

149. Feldman v. Commissioner, 186 F.2d 87 (4th Cir. 1950).

150. Stanton v. Commissioner, 189 F.2d 297 (7th Cir. 1951).

151. Surrey \& Warren, Federal Incone Taxation 846 (1954 ed.).

152. $5 \mathrm{CCH}$ Tax Ct. Mem. 528 (1946), cited in SuRREy \& WARREN, op. cit. supra note 151 , at 846 .

153. Ibid.

154. Helvering v. Clifford, 309 U.S. 331 (1940). See Edward D. Sultan, 18 T.C. 715, 724-25 (1952).

155. Commissioner v. Tower, 327 U.S. 280, 291 (1946). In his dissent in the Lusthans case Justice Reed distinguished the Clifford case as involving a short term trust rather than a partnership interest which not only was permanently to be the property of the wife, 
Clifford case for the point that income "must be taxed to him who earns it."150 But he also stated that the "Clifford-Horst" principle does not follow "automatically upon a gift to a member of one's family, followed by its investment in the family partnership."157 The Senate Report on the 1951 Act refers to cases "where the transferor retains so many of the incidents of ownership that he will continue to be recognized as a substantial owner of the interest which he purports to have given away...."15s This quotation suggests an approach to the problem to which the courts may have insufficiently resorted. What can be done to trusts can certainly be done to partnerships. It has not been done so far.

\section{The Use of Federal Tax Statutes to Enforce Local Law}

No discussion of Justice Black's attitude toward federal taxation would be complete without some reference to his vigorous dissent in Rutkin v. Unitcd States. ${ }^{159}$ In this case a slim majority of the Supreme Court, despite its previous $W$ ilcox decision ${ }^{160}$ that embezzled funds do not constitute income, gave its blessing to the use of the federal income tax to punish the local crime of extortion. Justice Black protested that the federal government would never collect substantial amounts of money from extortioners, and that the purpose of the policy implicit in the prosecution of Rutkin was "to give Washington more and more power to punish purely local crimes." 161 The majority decision, he thought, authorized "an expansion of Federal criminal jurisdiction into fields of law enforcement heretofore wholly left to states and local communities."162

The dissenting opinion of Justice Black went on to indicate the dangers of such a policy. Taking over enforcement of local criminal laws lowers "the prestige of the federal system of justice," and makes that system "top-heavy." "[T] he United States cannot perform the monumental tasks which lie beyond

but exposed her to partnership liability. Lusthaus v. Commissioner, 327 U.S. 293, 303 (1946). See opinion of Arundell, J., in Edward D. Sultan, 18 T.C. 715, 724 (1952); id. at 725 (Opper, J., dissenting opinion).

156. Commissioner v. Culbertson, 337 U.S. 733, 739-40, 745, 746, 748 (1949).

157. Id. at 746 .

158. S. Rep. No. 781, 82d Cong., 1st Sess. 39 (1951). See Comment, 61 Yale L.J. 541, 548 (1952).

159. 343 U.S. 130, 139 (1952). See also Justice Frankfurter's dissent in United States v. Kahriger, 345 U.S. 22, 37 (1953).

160. Commissioner v. Wilcox, 327 U.S. 404 (1946).

161. Rutkin v. United States, 343 U.S. 130, 141 (1952).

162. Ibid. Similarly, Justice Black protested in MoDonald v. Commissioner, 323 U.S. 57 (1944), where the Court decided that campaign expenses of a judge were not an allowable deduction. The protest was against an oblique attack on abuses in campaign expenditures "by strained statutory construction which permits a discriminatory penalty to be imposed on taxpayers who work for the states, counties, municipalities, or the federal government." The problem "should be attacked squarely by the proper state and fcderal authorities. ..." Id. at 71 (dissenting opinion). See also, "The Effectiveness of Present Federal Tax Statutes and Their Administration," address by Representative Cecil R. King, American Bar Association, Sept. 16, 1952. 
state power if the time, energy and funds of federal institutions are expended in the field of state criminal law enforcement."163

Justice Black, along with the three other dissenting Justices in the Rutkin case. was also concerned about the states. Local crimes-extortion, robbery and embezzlement, for example-are matters of local concern. The precise elements of these crimes, as well as the problems underlying them, vary from state to state. As former United States Attorney General Mitchell once pointed out, federal enforcement of local laws must of necessity tend to free the states from a sense of responsibility for their own local conditions. ${ }^{164}$ And, Justice Black added,

"Even when states attempt to play their traditional role in the field of law enforcement, the overriding federal authority forces them to surrender control over the manner and policy of construing and applying their own laws. ${ }^{105}$ State courts not only lose control over the interpretation of their own laws, but also are deprived of the chance to use the discretion vested in them by state legislatures to impose sentences in accordance with local ideas. Moreover, state prosecutors are deprived of the all-important function of deciding what local offenders should be prosecuted. Final authority to make these important decisions becomes located in the distant city of Washington, D.C. Here, as elsewhere, too many cooks may spoil the broth."160

The undue expansion of federal jurisdiction entails one more complicating factor. "Criminal rules of substance and of procedure vary widely among the jurisdictions. Punishment is frequently different. In fact, the same kind of conduct may be ignored as not worth criminal punishment by one jurisdiction while considered a serious criminal offense by another." 107

Justice Black's dissenting opinion in the Rutkin case also cited figures that showed in striking fashion that the federal government was using the federal tax statute to suppress local crime rather than to collect taxes-so that "it can hardly be said that Rutkin was tried for tax evasion."168 A total of only thirteen pages in a voluminous record of 900 pages had any reference to taxes. The re-

163. Rutkin v. United States, 343 U.S. 130, 141-42 (1952). "The Bureau as an agency primarily devoted to the problems of general revenue raising is ill-adapted to take on the duties of conducting a criminal investigation job outside the tax field." King, supra note 162 , at 5 .

164. 72 CoNG. REC. 6214 (1930).

165. In this connection Justice Black mentioned the necessity of determining "how much law of what state applies." He then suggested that this procedure denies an opportunity to obtain an authoritative decision on a matter of state law from the highest state court, thus introducing the problems involved in Erie v. Tompkins. Rutkin v. United States, 343 U.S. 130, 144 n.5 (1952).

166. Id. at $142-43$.

167. Id. at 144. Justice Black mentioned the example that under the Federal White Slave Law men can be imprisoned five years for conduct which many states would not regard as criminal at all. Ibid. He might have added the point that gambling-a forbidden activity in many states-is a legitimate activity in Nevada.

168. Id. at 145 . 
maining 887 pages were devoted to inflammatory aspects of Rutkin's past life and associations, including his bootlegging activities in Prohibition days and various charges of swindling made by Rutkin and others against one Reinfeld. Subsequent events have certainly proved the truth of Justice Black's suggestion that "if we are going to depart from the Wilco.r holding," the Rutkin case was "a poor case in which to do so." 169

The question discussed by Justice Black in this opinion remains important in connection with various attempts of the Internal Revenue Service to enforce federal and local public policy. From time to time the Commissioner and the Department of Justice ${ }^{170}$ have seemed to proceed on the theory that the Internal Revenue Code was more an essay on morality, designed and enacted to encourage virtue and discourage sin, than an attempt to raise revenue to detray the cost of government. ${ }^{171}$ Justice Black has sufficiently indicated his lack of sympathy with an extraneous use of a taxing statute to implement the public policy of the federal and state governments beyond the area of taxation. ${ }^{172}$ Taxes can be, and should be, a powerful instrument of economic and social policy. ${ }^{173}$ But, as the Supreme Court pointed out in its Wilcox opinion, "moral turpitude is not a touchstone of taxability."174 If they are dedicated to the purpose of improving men's hearts, ${ }^{175}$ tax laws should give plain notice of their commands. ${ }^{176}$ "A statute which either forbids or requires the doing of an act in terms so vague that men of common intelligence must necessarily guess at its meaning and differ as to its application" violates "the first essential of due process of law." 177 It likewise violates a first principle of sound tax policy, for the Commissioner is hardly an expert on morality or on the meaning of the

169. Id. at 147. See United States v. Rutkin, 212 F.2d 641 (3d Cir. 1954) ; Rutkin v. Reinfeld, 122 F. Supp. 265 (S.D.N.Y. 1954).

170. See "Freedom Under Law" Address by Attorney General Brownell, American Bar Association Convention, Aug. 27, 1953.

171. Or, as Member Sternhagen said in a dissenting opinion many years ago, "The revenue act was not contrived as an arm of the law to enforce State criminal statutes by augmenting the punishment which the State inflicts." Burroughs Bldg. Material Co., 18 B.T.A. 101, 105, aff'd, 47 F.2d 178 (2d Cir. 1931).

172. See Commissioner v. Heininger, 320 U.S. 467 (1943) ; cf. Lilly v. Commissioner, 343 U.S. 90 (1952) ; Commissioner v. Pacific Mills, 207 F.2d 177 (1st Cir. 1953) ; National Brass Works v. Commissioner, 182 F.2d 526 (9th Cir. 1950) ; Jerry Rossman Corp. v. Commissioner, 175 F.2d 711 (2d Cir. 1949); Heininger v. Commissioner, 133 F.2d 567, 570 (7th Cir. 1943).

173. See Blough, The Federal Taxing Process 409, 463 (1952) ; Paul, Taxation For Prosperrty 201 (1947); cf. Paul, The Use of Public Policy by the Commissioner in Disallowing Deductions, in Major Tax Problens of 1954, U. So. Callf. Tax Inst. 715.

174. Commissioner v. Wilcox, 327 U.S. 404, 408 (1946).

175. Cf. Commissioner v. Pacific Mills, 207 F.2d 177 (1st Cir. 1953).

176. Helvering v. City Bank Farmers Trust Co., 296 U.S. 85, 89 (1935).

177. Connally v. General Constr. Co., 269 U.S. 385, 391 (1926). See also Douglas, J., dissenting in United States v. Harriss, 347 U.S. 612, 628 (1954); cf. Commissioner v. Glenshaw Glass Co., 348 U.S. 426, 431 (1955), holding that "payments . . extracted from . . . wrongdoers as punishment for unlawful conduct" retain their character as "taxable income to the recipients." 
statutes and public policies of forty-eight states and the many nontax statutes passed by Congress.

Taxpayers are entitled to know, at least with a fair degree of certainty, the basis of claims against them. ${ }^{178}$ Certainty is not altogether attainable; we cannot make tax statutes as plain as the Ten Commandments. ${ }^{179}$ But the Commissioner can take the statute as he finds it, leaving to other authorities the job of specifying sanctions for the enforcement of statutes having nothing to do with taxes. For, in the incisive words of an English jurist, public policy is "a very unruly horse, and when once you get astride it, you never know where it will carry you." 180 It sometimes carries the Treasury further than it wants to go, and taxpayers to a point of financial ruin on account of transactions involving less than clearly proved technical guilt, and at most mere technical guilt, but no moral turpitude whatever.

\section{Conclusron}

The measure of any man in public life, not excluding a Justice of the $\mathrm{Su}$ preme Court, must be in terms of the problems presented by the times in which he serves. The Supreme Court is not an ivory tower. It is true that its Justices are insulated from political activity. But they occupy key positions near the center of the country's national life. They are on a big stage. Their audience is a large one, and sometimes, properly, a highly critical one. ${ }^{181}$ They must

178. General Util. \& Operating Co. v. Helvering, 296 U.S. 200, 206 (1935). See also Thomas B. Lilly, 14 T.C. 1066, 1088 (1950) (Arundell, J., dissenting opinion).

179. See J. N. Frank, Law and the Modern Mind 325 (1930); Paul, Taxation FOR Prosperity 410 (1947).

180. Burroughs, J., in Richardson v. Mellish, 2 Bing. 229, 252, 130 Eng. Rep. 294, 303 (C.P. 1824).

181. As Holmes once said, "one may criticize even what one reveres." HoLmes, CoLlecten Legal Papers 194 (1952). To quote another, possibly less eminent Justice of the Court:

"It is a mistake to suppose that the Supreme Court is either honored or helped by being spoken of as beyond criticism. On the contrary, the life and character of its justices should be the objects of constant watchfulness by all, and its judgments subject to the freest criticism. The time is past in the history of the world when any living man or body of men can be set on a pedestal and decorated with a halo. True, many criticisms may be, like their authors, devoid of good taste, but better all sorts of criticisms than no criticism at all. The moving waters are full of life and health; only in the still waters is stagnation and death.

"I remember seeing in an eastern paper immediately after the decision in the well known income tax case a most extravagant eulogy upon the Supreme Court as a great defender of the rights of the few States against the many and of the accumulation of property against unconstitutional assaults. And when thereafter by that Court the act of Congress denouncing all contracts, combinations and conspiracies in a restraint of trade was held applicable to a combination between railroads to prevent competition in rates, that same paper contained an article expressing the most extraordinary surprise that men supposed to be of ordinary intelligence could be guilty of such a stupid blunder.

"The one article could be condensed in a single clause, 'a Daniel come to judgment; yea, a Daniel,' and the other in the equally short and expressive phrase, 'An ass within 
supply their own script. In the sense that they can deal only with cases and controversies presented to the Court their range of effective action is a limited one; even in the decision of those cases the writer of a majority opinion may have but a narrow scope to express his ideas. ${ }^{182}$ But most controversial issues usually manage to find their way to the Court, and this means that each Justice must take a position on one side or the other of these issues. And in another sense the Justices have almost boundless freedom in dealing with the questions which reach them. The answers to many of these questions, which affect $170,000,000$ people for better or for worse, cannot be found among reported precedents. Nor can strict logic supply solutions to the complex riddles involved in the imponderable problems of modern law in America. Answers must come from a deeper source. They must depend in the last analysis upon the feelings and intuitions and theories and sense of policy of the individual Justices on the Court. Their collective will must be done on a large part of the earth. for the Court is a court of last resort.

This means that the Court has a grave and delicate responsibility. The responsibility may be greatest in the field of constitutional law where the process of constitutional amendment is long and slow. ${ }^{183}$ If we would keep the Constitution in harmony with the activities of modern America, and the power of government "unrestrained by the social or economic theories one set of judges may entertain," the Constitution must not be an "ark of the covenant, too sacred to be touched."184 It is therefore important that the Supreme Court be ever ready to re-examine its own doctrines. "Stare decisis embodies an important social policy. It represents an element of continuity in law, and is rooted in the psychologic need to satisfy reasonable expectations." 185 "It is a strong tie which the future has to the past." 186 But it is a principle of policy, and not a mechanical formula to be followed even in response to pleas to let Congress correct mistakes that the Court has made. For "legislative correction of judicial errors is often difficult to effect."187

The responsibilities of the Supreme Court have been especially heavy during Black's incumbency. He came to the Court at an anxious time. The disturbance then enveloping the Court was part of a crisis facing the whole country. Urgency has changed its character since 1937, but it has not abated. The problems of depression have become problems of prosperity. It is not a serene

a lion's skin.' Now, it is the inalienable right of every American citizen according to the peculiar construction of his organs of hearing to recognize in the judgments of that Court either the voice of a Daniel or the braying of an ass."

Brewer, Government by Injunction, 15 NAT'L CoRp. REP. 848, 849 (1898).

182. See text at note 68 supra.

183. Douglas, Stare Decisis, 49 Colun. L. Rev. 735, 754 (1949).

184. Letter from Thomas Jefferson to Samuel Kerchival, July 12, 1816, quoted in Douglas, supra note 183 , at 754 .

185. Helvering v. Hallock, 309 U.S. 106, 119 (1939).

186. Douglas, supra note 183 , at 736 .

187. Id. at 746-47. 
prosperity, but rather a nervous prosperity which feeds on war and rumors of war. And the problems that have been solved are few compared to the many that remain to be solved. This is especially true in the field of taxation, where the work of the Court involves the interpretation of some of the most complex statutes enacted by Congress. Words being what they are-or the little they are-it is not an easy task to discover the policy of these statutes. The statutes deal with an intensely important, but difficult, subject. ${ }^{188}$ They are too often hastily drafted. But they represent an attempt to deal with problems intimately associated with the development of the economy and with the welfare of the whole social fabric.

Against this background I venture to suggest that Justice Black has served the Court well in matters of taxation. It cannot be said that his most important work has been in tax territory, but it can be said that what he has done in that area has been highly useful. It has been in the same pattern as his other work. Evidently believing that confidence based upon understanding is more enduring than confidence based upon awe, ${ }^{189}$ he has advocated full disclosure when a precedent was being overruled. He has been willing to correct judicial error even where correction might be effected by legislation. In the tricky area of tax avoidance, where questions of degree abound, ${ }^{190}$ his attitude has been a balanced one. He has been unwilling to sanction tax avoidance schemes and contrivances that lacked reality, but he has not tried to be the keeper of the congressional conscience. He has bowed his head in obedience to legislative mandate where Congress has drawn a line and the taxpayer has been on the safe side of that line. He has respected the principle that different tax consequences may flow from different methods of accomplishing the same ultimate economic result, and that taxpayers are entitled to select the method that results in the lower liability. ${ }^{101}$ And finally, though he has been called a "social reformer,"102 the Justice has resisted the great temptation to which some judges succumb in tax cases. Knowing that the federal tax statute is a federal statute, and that its use to suppress state and local crime involves grave dangers for our system of government, he has protested against the use of a federal tax statute, directed to the raising of revenue and to the economic welfare of the nation as a whole, for the improvement of men's hearts and the accomplishment of moral reform. ${ }^{193}$ Many will hope that his dissent in the Rutkin case will be an effective appeal to the better intelligence of a future day. ${ }^{194}$

A virtually unanimous public opinion sustains the proposition that Hugo Black has responded with distinction to the needs of the times which brought him to the Supreme Court. His federal tax opinions have maintained the

188. See Hand, Thomas Walter Swan, 57 Yade L.J. 167, 169 (1947).

189. Cf. id. at 754 .

190. See Harrison v. Schaffner, 312 U.S. 579 (1941); Irwin v. Gavit, 268 U.S. 161

(1925).

191. See Paul, The Lawyer as a Tax Adviser, 25 Rocky Mr. L. Rev. 412 (1953).

192. Jaffe, MIr. Justice Jackson, 68 'HARv. L. Rev. 940, 997 (1955).

193. See Paul, Taxation in the United States 698 (1954).

194. See text at note 63 supra. 
standards of his other work on the Court. Those are high standards, indeed. But no standards can be too high, for tax law is a dynamic and exacting subject. The solution of the problems it presents to the Court in days to come will call for the most meticulous attention to legal detail and a highly developed sense of policy. Justice Black has demonstrated that he has the qualities the Court needs in its tax work. His long experience should help the Court greatly as it goes forward with the task of guiding lower courts in their important work of interpreting tax statutes in the light of the needs of a nation faced with the fiscal, as well as many other, necessities of leadership in a disorganized and troubled world. 


\title{
THE YALE LAW JOURNAL
}

VOLUME 65 FEBRUARY, $1956 \quad$ NUMBer 4

\author{
EDITORIAL BOARD \\ Norbert A. SCHLEI \\ Editor-itr-Chief
}

DAvid B. IsBeIL
Article and
Book Review Editor

IRving J. AlteR

BENIAMIN H. BALKIND

MaLvin E. Bank

JoHN W. BarNUAS

Axel H. Baum

MELUTN L. BeDRICK

C. Willianr Berger

DANIEL M. BERGER

Neil. N. Bernstein

RoBERT W. BLANCHETTE

JUdiTH MYYRA BLEICH

J AMIES H. BRATTON, JR.

Alan P. ColODNY

EDMUND V. Conway

I. RICHARD DUFFIELD

H. EDw. DuNkEtberger, JR.

RODNEY E. EYSTER

GERALD T. FLOM

\author{
GERALD MI. DOPPELT \\ JON $O$. NEWMAAN \\ RICHARD H. PERSHAN \\ Note and Comment Editors
}

\author{
Stephen J. Pollak \\ Managing Editor
}

\author{
Barbara A. LindemanN \\ Ralph C. MEnapace, JR. \\ Edward A. Miller \\ GaBRIEL ORECEKOFF \\ Otis P. Pearsall \\ ROBERT S. REDMOUNT \\ MARUIN N. RTMMI \\ BERNARD S. ROBBINS \\ RAy MaUry SHainberg \\ WALTER E. SHUTTLEWORTH \\ ROBERT J. SISK \\ ARLEN SPECTER \\ JoHN T. SUbaK \\ Charles W. Thongasson \\ CharLes $H$. VEJVODA \\ Frank E. G. WeIL \\ STEPHEN A. WEINER \\ HowARD P. WhLENS
}

Marie McMiahon

Business Secretary

The special nature of this issue calls for a special word of explanation. The idea of a Festschrift to celebrate Justice Black's seventieth birthday was put forward a year ago by Professor Cahn, and was promptly and delightedly seized upon by the editors of the Journal. We asked the Justice for his permission, but he declined to assert any right of consent or objection. "Judges and their work are in a way a part of the public domain subject to public discussion," he wrote, "and law journals are peculiarly suited to carry on such discussions .... I think law journals can do their job best if they can perform their functions with the same independence judges do."

With this independence, we sought to assemble a group of contributors at once eminent and close to the Justice; and from them to secure not a compre- 
hensive, symposium-style evaluation of Justice Black's work but a collection of pieces touching on aspects of either his work or his interests. Such are the leading articles in this issue; and such are the authors listed below.

The list is smaller by two names than we had hoped. Not every subject we should have liked to deal with has been included here-we were unable to secure an appropriate piece on admiralty, the subject that, more than any other, Justice Black has made uniquely his own province on the Court. And not every author whom we should have liked to include, and who wished to be included, was able to join us. Judge Jerome Frank, overtaken by an unseasonal surge of work on the Second Circuit, was forced to postpone to a later issue a piece he had promised for the Festschrift.

The final note is a sorrowful one. Mr. Randolph Paul, after he harl made his substantial contribution to the project, was suddenly taken from us. Some sense of the magnitude of the loss is, we hope, conveyed on page 495 : some sense of the distinction of the man is to be found below.

\section{CONTRIBUTORS TO THIS ISSUE}

'William O. Douglas. A.B. 1920, Whitman College; LL.B. 1925, Columbia University. Associate Justice, Supreme Court of the United States.

Eugene V. Rostow. B.A. 1933, LL.B. 1937, M.A. 1944, Yale University. Dean of the Yale Law School.

JoHN P. FRANK. B.A. 1938, M.A. 1940, LL.B. 1940, University of Wisconsin; J.S.D. 1947, Yale University. Member of the Arizona Bar. Former law clerk to Justice Black. Author: Mr. Justice Black, The Man and His Opintons (1949); Cases and Materials on Constitutional Law (rev. ed. 1952) ; Cases on the Constitutuon (1951).

EdMond CahN. Professor of Law, New York University School of Law. Author: THF Sense of Injustice (1949); The Moral Decision (1955). Editor and contributor: Supredie Court and Supreare Law (1954).

Leon Green. B.A. 1908, Ouachita College; LL.B. 1915, University of Texas. Professnr of Law, University of Texas. Formerly Professor of Law, Yale University, Dean of Northwestern University School of Law. Author: Ratronale of Proximate Cause (1927): Judge and Jury (1930); The Judictal Process in Tort Cases (2d ed. 1939); Casps on Injuries to Relations (2d ed. 1953).

Randolph E. Paul. B.A. 1911, Amherst College; LL.E. 1913, New York Law School. Late member of the District of Columbia, New Jersey and New York Bars. Occasional Special Tax Consultant to the Secretary of the Treasury and the President of the United States, 1937-1941; Assistant and Tax Advisor to the Secretary of the Treasury, 1941-1942; General Counsel of the Treasury and Tax Advisor to the Secretary of the Treasury, 1942-1944; Special Assistant to the President in 1946. Recipient. in 1946, of the Ames Medal, awarded periodically by the faculty of Harvard Law School "for the most meritorious law book or legal essay written in the English language." Author : STtnres in Federal Taxation (1937, 1938, 1940); Federal Estate and Gift Taxation (1942, 1946 Supp.) ; Taxatton for Prosperity (1947) ; Taxatron in the United States (1954). Co-author (Mertens): Law of Federal Income Taxation (1934). 